\title{
Intertidal boulder transport: a proposed methodology adopting Radio Frequency Identification (RFID) technology to quantify storm induced boulder mobility
}

Linley John Hastewell, Martin Schaefer, Malcolm Bray \& Robert Inkpen

\begin{abstract}
Boulder transport is an area of growing interest to coastal scientists as a means of improving our understanding of the complex interactions between extreme wave activity and the evolution of rocky coasts. However, our knowledge of the response of intertidal boulder deposits to contemporary storm events remains limited due to a lack of quantifiable fieldbased evidence. We address this by presenting a methodology incorporating Radio Frequency Identification (RFID) tagging and Differential Global Positioning Navigation Satellite System (DGNSS) technology to monitor and accurately quantify the displacement of RFID tagged boulders resulting from storm wave activity. Based on preliminary findings we highlight the suitability of the technology and methodology to better understand the spatial and temporal response of intertidal boulders to contemporary storm events.We inserted RFID tags in 104 limestone boulders (intermediate axes from 0.27 to $2.85 \mathrm{~m}$ ) across a range of morphogenic settings at two sites on the intertidal shore platforms at Bembridge, Isle of Wight (UK). Fifteen topographic surveys were conducted between July2015 and May 2017 to relocate and record tagged boulder locations (tag recovery rate: 91\%). The relocated boulder coordinate data from both sites identified 164 individual transport events in 63\% of the tagged boulder array amounting to $184.6 \mathrm{~m}$ of transport, including the displacement of a boulder weighing more than 10 tonnes.Incidents of boulder quarrying and overturning during transport were also recorded, demonstrating that despite the relatively sheltered location, intertidal boulders are created and regularly transported under moderate storm conditions. This suggests that contemporary storm events have a greater propensity to mobilise boulders in the intertidal range than has previously been realised. Consequently, by documenting our methodology we provide guidance to others and promote further use of RFID technology to enable new hypotheses on boulder transport to be tested in a range of field settings and wave regimes.
\end{abstract}


1 Intertidal boulder transport: a proposed methodology adopting Radio

2 Frequency Identification (RFID) technology to quantify storm induced boulder

3 mobility.

4

5

6 Keywords: RFID tagging, boulder transport, storm events, sediment tracing,

7 coastal change

\section{$8 \quad$ INTRODUCTION}

9 The anticipated increase in storm activity and intensity resulting from climate change

10 (Easterling et al., 2000; Beniston et al., 2007) is expected to drive geomorphic

11 alteration to shore platforms and increase the vulnerability of coastal zones globally

12 (Paris et al., 2011). Given the irreversible erosional impact of storm waves on rocky

13 coasts (Naylor et al., 2010) understanding the geomorphic response to such events

14 is of growing significance. As a result, storm wave impacts on rocky coasts are of

15 increasing interest in terms of understanding landform evolution and monitoring

16 coastal change.

17 The presence of large boulders on shore platforms is testament to the dynamic

18 nature of the coastal environment. However, the mechanisms that facilitate

19 detachment, transport and deposition of boulder-sized sediment within the intertidal

20 zone are poorly understood. We defined boulders as clasts with an intermediate $(I)$

21 axis between 0.25 and 4.1m (Blair and McPherson, 1999).

22 Sediment tracing provides a means of monitoring and quantifying displacement while

23 offering an insight to the hydrodynamic conditions that enable episodes of mobility 
24 (Lee et al., 2000; Sear et al., 2000). The basic principle of sediment tracing is to

25 introduce material to a study site which is distinct from, yet accurately reflects the physical properties (e.g. particle size, shape and density) of the indigenous sediment

(Sear et al., 2000; Lee et al., 2007; Black et al., 2007). This can be achieved using artificial tracers such as aluminium cast material (Bray et al., 1996) or by adapting the indigenous material found at the selected study site. Following tracer deployment, successive searches are undertaken to recover the particles and record

31 their precise location allowing distance, direction and frequency of transport to be 32 determined.

In littoral settings sediment tracers are monitored in-situ where they are subjected to a series of site specific conditions (e.g. wave climate, tidal regime, topography and bathymetry) which are difficult, if not impossible to accurately replicate within the confines of the laboratory. This paper demonstrates the feasibility of using Radio Frequency Identification (RFID) technology in combination with periodic topographic surveys using Differential Global Positioning Navigation Satellite System (DGNSS) to accurately quantify the mobility of intertidal boulders resulting from contemporary storm activity.

Historically, tracer techniques have included painted sediment (Russell, 1960; Jolliffe, 1964; Nordstrom and Jackson, 1993); radioisotopic tracers (Steers and Smith, 1956; Kidson et al., 1958), magnetic tracers (Osborne, 2005), aluminium tracers (Wright et al., 1978), electronic radio transmitters (Bray et al., 1996) and RFID's (Dickson et al., 2011; Dolphin et al., 2016) as a means of monitoring littoral sediment transport across a range of particle sizes. The development of tracer techniques has been driven by the need to improve tracer recovery rates over broader timescales. Table 1 identifies how different tracer methods and technological 
49 advances have facilitated this. It also highlights the preponderance of research

50 focusing on pebble and cobble-sized particles, and subsequently, the paucity of long

51 term tracer studies relating specifically to the mobility of boulder-sized clasts. Further

52 reviews pertaining to the development of sediment tracing techniques have been

53 published by Sear et al. (2000) and Chapuis et al. (2014).

\section{$54 \quad$ Insert table 1.}

55 RFID tagging has proven to be effective in transport studies in both fluvial (Bradley \& 56 Tucker, 2012; Liébault et al., 2012) and littoral settings (Allan et al., 2006; Dickson et 57 al., 2011; Dolphin et al., 2016). It has facilitated longer term monitoring studies 58 yielding more favourable recovery rates when compared with alternative methods.

59 The success of previous RFID-based studies documenting sediment transport was 60 integral to our decision to adopt this technology for monitoring boulder displacement.

61 It is well documented that storm waves have the ability to detach, transport and 62 deposit boulders on intertidal shore platforms (Stephenson and Naylor, 2011; Paris 63 et al., 2011; Etienne and Paris, 2010; Barbano et al., 2010; Goto et al., 2011; Biolchi 64 et al., 2016; Shah-hosseini et al., 2011; Cox et al., 2012). Boulder accumulations on 65 shore platforms frequently develop distinctive geomorphic features such as clusters, ridges, fields and cliff top deposits (Nott, 2003a; Paris et al., 2011). These boulder assemblages have been used to infer the mechanisms by which detachment, transport and emplacement occur, including past tsunamigenic wave events (Engel and May, 2012; Nandasena et al., 2013; Mottershead et al., 2014; Etienne et al., 2011; Goto et al., 2012) and contemporary storm activity (Hall, 2011; Fichaut and

71 Suanez, 2011; Autret et al., 2016, Cox et al., 2018). However, despite growing 72 interest in the effects of extreme waves the subsequent modes and rates of boulder 
73 transport over time are poorly understood owing to a lack of accurate, reliable and

74 quantifiable field data (Goto et al., 2011; Paris et al., 2011; Moses, 2014).

75 Recent studies have sought to address this by documenting boulder transport

76 during, and resulting from, contemporary storm events. Extreme storm activity

77 occurred in the winter of 2013-2014 which had a dramatic impact on the Atlantic

78 coastline of Europe (Masselink et al., 2016a) with reports of significant wave heights

79 exceeding 9m (Castelle et al., 2015). During this period Autret et al. (2016) recorded

80 the morphological and sedimentological alteration of cliff-top boulder deposits. They

81 documented quarrying of 178 clasts, one weighing 86 tonnes, and the transport of

82507 blocks some as far as $40 \mathrm{~m}$ inland at elevations up to $14 \mathrm{~m}$ above mean sea

83 level. This was achieved using unmanned aerial vehicles (UAV's) and kite-mounted

84 cameras which were deployed to obtain pre/post site imagery for comparative

85 purposes. These techniques were complimented by field observations of boulder

86 mobility and the use of pressure sensors to establish hydrodynamic conditions

87 during the period of storm activity.

88 Stephenson and Naylor (2011) and Naylor et al. (2016) employed marine paint as a

89 tracer to document evidence of periodic detachment, entrainment, deposition and the

90 breakdown of boulders. The latter study quantified the transport distance of fine and

91 medium-sized boulders and is thought to be the first intra-storm assessment of

92 boulder transport. Using painted tracers an $81 \%$ recovery rate $(n=39 / 48)$ was

93 achieved over a four day monitoring period. Despite the valuable insights gained

94 from these studies the paint methodology has limitations, as follows: (1) the reliance

95 on visual detection prevents relocation of buried tracers resulting in reduced rates of

96 recovery; (2) the paint coating may arouse unwanted attention and encourage

97 anthropogenic transport; (3) prolonged exposure leads to paint abrasion limiting the 
98 longevity of the study; (4) being visually obtrusive issues may arise with gaining

99

100

101

102

103

104

105

106

107

108

109

110

111

112

113

114

115

116

117

118

119

120

121

122 authorisation for the use of painted tracers in sensitive and designated coastal

locations. These factors suggest an alternative, more discreet technique is required

for effectively tracing boulder displacement over monthly and annual timescales,

RFID tagging provides a viable alternative. Furthermore, with a non-visual mode of

detection, RFID tags allow for the relocation of buried clasts, resulting in improved

rates of recovery (Bray et al., 1996).

Despite the potential of RFID tags for quantifying boulder transport (Paris et al., 2011) their use has focused predominantly on mixed gravels and cobbles (Allan et al., 2006; Miller et al., 2011; Dolphin et al., 2016) opposed to boulder-sized clasts (Table 1). The limited use of RFID's to monitor boulder displacement may be due to perceived limitations with the technique, identified by Paris et al. (2011) and Naylor et al. (2016). Specifically, the ability of the tags to remain operational, concerns with clast breakdown and the ability to recover tagged material in a short tidal window. To date, we are aware of only one study that has incorporated the use of RFID's in monitoring clast mobility that extends into the boulder size range (Brayne, 2015); where the maximum size classification used was fine boulders with an intermediate axis up to $0.51 \mathrm{~m}$. We broaden the scope of this previous work and allay concerns with the use of RFID's having conducted the first known field investigation applying RFID tagging to boulder-sized clasts only, from fine through to very coarse boulders.

We embedded RFID tags in 104 limestone boulders across two sites, Bembridge Ledge $(n=50)$ and Black Rock $(n=54)$ at Bembridge, Isle of Wight, U.K. Boulders were selected from the indigenous sediment to reflect a range of shapes, particle sizes and morphological settings. Between July 2015 and May 2017 fifteen topographic surveys were conducted to relocate tagged boulders. Recovered 
123 boulder positions were recorded using DGNSS; the collated data providing a spatial 124 and temporal context to boulder displacement. This coordinate data was processed 125 using a tailored python script (included in the supplementary documentation) which 126 calculates the distance and azimuth between successive points.

127 The focus of this paper is the RFID methodology. We describe in detail the 128 procedures undertaken and recommend a series of considerations, highlighting best 129 practice for successful field tag deployment and monitoring. We draw upon incidents 130 of mobility from the field surveys to illustrate the capability and effectiveness of the 131 methodology for use in future boulder transport studies.

\section{RFID METHODOLOGY}

\section{RFID operational overview}

134 The term RFID describes the various technologies that utilise radio waves to identify 135 objects (Aluf, 2017). It has been integrated into numerous mainstream applications, 136 primarily as a means of asset tracking. RFID technology comprises four key 137 components, a transponder, more commonly referred to as a tag, an antenna, a 138 reader and a user interface (PDA), Figure 1.

\section{Insert figure 1.}

1401 - RFID TAGS (transponder): the tags enclosed circuitry is housed within a 141 hermetically sealed glass casing. Each tag is pre-programmed with a unique 16-digit 142 ID code allowing for the unequivocal identification of an individual object, in this 143 instance a boulder.

1442 - POLE ANTENNA: connected to the reader via a cable the circuitry housed within 145 the antenna tubing emits and receives electromagnetic signals via the circular loop. 
146 The pole is operated in the field in a sweeping movement, similar to that of a

147 conventional metal detector.

1483 - BACKPACK READER: powered by a 14.8 volt lithium polymer (Li-Po) battery the

149 reader is housed in a backpack. It produces a low frequency $(134.2 \mathrm{kHz})$

150 electromagnetic signal which is transmitted via the pole antenna.

1514 - HANDHELD COMPUTER (PDA): featuring specialist software that enables the

152 identification of the unique tag ID number. This is wirelessly connected to the reader

153 via a Bluetooth adapter.

154 Tag detection occurs when the pole antenna comes within range of a deployed tag,

155 detection range details are documented in Table 2. The emitted electromagnetic

156 signal from the loop of the pole antenna provides sufficient power to prompt tag

157 activation. The tag becomes energised and transmits a return signal containing the

158 unique tag ID code which is received by the antenna and relayed to the reader. An

159 audible alarm also alerts the user to the detection of a tag. The return signal is

160 translated by the reader and transmitted via the Bluetooth functionality to the PDA or

161 alternative mobile device, notifying the user of the tag ID code (Figure 2).

\section{Insert figure 2.}

163 RFID tags can be described as active or passive in their operation (Nichols, 2004).

164 Active tags require a power source (e.g. a battery) which renders them impractical

165 for sediment tracking purposes based on size, cost and longevity of operation.

166 Passive tags, also referred to as Passive Integrated Transponder (PIT) tags have no

167 internal power source making them smaller (tag sizes of $12 \mathrm{~mm}, 23 \mathrm{~mm}$ and $32 \mathrm{~mm}$ in

168 length are available). Without the need for a battery the tags have a potentially 
169 unlimited operational capacity (Want, 2006) although Allan et al. (2006) suggest a 170 more conservative 50 year lifespan.

171 RFID systems are available from a variety of sources. We selected a field ready

172 solution supplied by Oregon RFID as the manufacturer's specification fulfilled our

173 criteria of tag detection ranges approaching $1 \mathrm{~m}$.

174 Typically, existing tracer techniques rely on the collection and removal of sediment

175 from a study site for tagging in the comfort of a laboratory with access to a range of 176 specialist equipment (Dickson et al., 2011; Allan et al., 2006). Size constraints

177 dictate boulder tagging must be conducted in the field. This generates a number of

178 novel issues which require consideration prior to, and during tag deployment to

179 ensure a successful monitoring campaign. These will be addressed herein.

180 Site selection and description

181 A pre-requisite of any proposed site is the presence of coarse clastic material known

182 to be mobile during periods of increased wave activity. Accessibility is a key

183 consideration as site visits may be required at short notice in response to storm

184 activity. Further consideration is afforded to the locality of wave recording devices to

185 establish hydrodynamic conditions relating to specific storm events which provides

186 insight to the wave thresholds required to initiate transport.

187 Bembridge is located at the most easterly point of the Isle of Wight $\left(50.6883^{\circ} \mathrm{N}\right.$, -

$\left.1881.06982^{\circ} \mathrm{W}\right)$, Figure 3. It was selected as it fulfils the aforementioned criteria. We

189 selected two field sites, Bembridge Ledge and Black Rock Ledge upon which 104

190 RFID tags were inserted into boulders of varying size and shape $(n=50$ and $n=54$

191 respectively). Each site covers an area of approximately $0.1 \mathrm{~km}^{2}$. Boulders are 
192 distributed across both sites either as individual, solitary clasts, or collectively as

193

194

195

196

197

198

199

200

201

202

203

204

205

206

207

208

209

210

211

212

213

214

215 clusters or as distinct assemblages such as boulder ridges. The nearest wave buoy, operated by the Channel Coast Observatory $(\mathrm{CCO})$ is located approximately $5 \mathrm{~km}$ to the southwest of the study site at Sandown Bay. The buoy is positioned $1.2 \mathrm{~km}$ from the coast in a water depth of $10.7 \mathrm{~m}$ (chart datum). There is also a tidal gauge recording wave and tidal parameters located on Sandown Pier (Figure 3c). Wave, tidal and selected meteorological parameters are recorded every 30 minutes (CCO, 2017a).

The area is classified as meso-tidal with a spring and neap tidal range of $3.7 \mathrm{~m}$ and $1.8 \mathrm{~m}$ respectively. Current research relating to boulder transport has focused on site locations with considerable fetches (Scheffers et al., 2009; Switzer and Burston, 2010; Noormets et al., 2004). Comparably, Bembridge has a limited fetch (Figure $3 d$ ), its eastern aspect providing shelter from large Atlantic swell waves and the prevailing south westerly wind and wave direction. Bembridge Ledge is east facing opposed to Black Rock with its southern aspect which is more exposed to wave activity.

Average wave direction is dominant in the southern quadrant with a mean of $164^{\circ}$ over the 22 month study period (July 2015 - May 2017). Average significant wave height $\left(H_{s}\right)$ was $0.6 \mathrm{~m}$ and a maximum wave height $\left(H_{\max }\right)$ of $6.8 \mathrm{~m}$ was recorded over the same period (CCO, 2017b).

\section{Insert figure 3.}

A key feature of the Bembridge coastline is an extensive series of intertidal terraced shore platforms that extend up to $500 \mathrm{~m}$ seaward at its widest point. The platforms are characterised by an abrupt terminus, akin to the type-B shore platform as 
216 described by Sunamura (1992). The platforms are formed of well jointed, near

217 horizontally bedded Late Eocene Bembridge Limestone (Daley \& Edwards, 1990;

218 Armenteros \& Daley, 1998). The limestone beds are interspersed by thin layers of

219 Bembridge Marl which are preferentially eroded creating an overburden of the more

220 consolidated limestone. The overburden, coupled with dense bedding and jointing

221 facilitates the liberation of blocks from the shore platform edge (Trenhaile 2002;

222 Knight et al., 2009; Hall, 2011). Block removal, or quarrying, occurs when waves

223 break against fractured rock structures resulting in increased pressure within air-filled

224 joints (Stephenson and Kirk 2000, Knight and Burningham 2011). Increased wave

225 impact pressures promote crack propagation leading to boulder quarrying (Müller et

226 al., 2003). Many of the Bembridge boulders (including RFID tagged clasts) originate

227 from the quarrying process, and are therefore, created, and subsequently

228 transported and deposited by wave activity within the intertidal zone (Figure 4).

\section{$229 \quad$ Insert figure 4.}

230 Tag selection

231 RFID tags used in sediment tracing are available in three sizes, $12 \mathrm{~mm}, 22 \mathrm{~mm}$ and

$23232 \mathrm{~mm}$. The choice of tag size depends on; (1) the size of clast to be tagged: the tag

233 required needs to be smaller than the clast into which it is being inserted; (2) the

234 likelihood of clast burial: the smaller the clast size the greater the likelihood of burial,

235 therefore the vertical tag detection range requires consideration; (3) the required tag

236 detection range: the distance across which a tag can be detected is contingent on a

237 number of factors including tag size, tag orientation, proximity of noise (e.g. electrical

238 appliances), reader battery level and antenna diameter (Oregon RFID, 2017; Allan et

239 al., 2006; Chapuis et al., 2014). To maximise the tag detection range we selected 
$24032 \mathrm{~mm}$ tags thus increasing the likelihood of tag recovery (Chapuis et al., 2014;

241 Oregon RFID, 2017).

242 As part of the pre-deployment testing we conducted a series of laboratory trials to 243 establish the significance of tag orientation on the detection range. We placed the $24432 \mathrm{~mm}$ RFID tag horizontally on the floor aligned along the north-south axis with the 245 visible copper wire circuitry (Figure 5) orientated north, $0^{\circ}$, replicating Chapuis et al. 246 (2014). We approached the tag from the north, east, south and west with the 247 antenna elevated $0.1-0.2 \mathrm{~m}$ above the ground. When the audible detection alarm 248 was activated we recorded the distance from the end of loop antenna to the tag. 249 Testing was conducted on 5 different tags with 20 approaches from the 250 aforementioned cardinal directions. The results identified that approaching the tag 251 'head on' from the north towards the copper coil tag end provided a greater read 252 range than from any other direction (Table 2). We recorded a mean detection range 253 of $0.77 \mathrm{~m}$, within $15 \%$ of the manufacturer's published detection range of $0.89 \mathrm{~m}$ 254 (Oregon RFID, 2017). Similar experimental analysis by Chapuis et al. (2014) 255 suggested approaching the tag from the northeast maximises tag detection although 256 this was based on $23 \mathrm{~mm}$ tags opposed to $32 \mathrm{~mm}$.

\section{Insert table 2.}

258 Prior to insertion within the boulder, tags were checked in the laboratory to ensure 259 operational functionality by placing them within range of the antenna. The last four 260 digits of the transmitted tag ID were noted. Tags were placed in a protective silicone 261 sleeve to provide additional protection from impact forces during displacement.

262 The ends of the sleeved tag were capped with a waterproof sealant and allowed to 263 cure. This created a waterproof seal around the tag providing further protection and 
264 prolonging operational use. The silicon sleeve was numbered with the last 4-digits of

265 the tag ID code and the copper coiled end was marked for identification in the field at

266 the time of insertion (Figure 5).

\section{Insert figure 5.}

\section{Boulder selection}

269 Prior to selecting boulders for tagging a number of factors should be considered as

270 they can affect the ability to successfully relocate and record boulders within a single

271 tidal cycle. These include site terrain, tidal regime, spatial distribution of tagged

272 boulders, the number of RFID tag detectors, and the availability of field assistance.

273 Additionally, wave climate requires consideration as this has the ability to disperse

274 tracers across a wider area extending the time required to relocate tagged clasts.

275 A key factor in tracer studies relates to the effectiveness of the introduced material to

276 accurately reflect the physical properties, namely size and shape of the indigenous

277 sediment (Black et al., 2007). This was achieved by measuring a random selection of

278100 indigenous boulders at each of the two Bembridge sites, recording the long $(L)$,

279 intermediate $(I)$ and short $(S)$ axial dimensions. These measurements were also

280 used to establish boulder shape as characterised by Zingg (1935). Comparisons of

281 size and shape between the indigenous and tagged boulders are presented in Table

282 3. The values express a degree of similarity between the two populations.

\section{Insert table 3.}

284 Samples of the Bembridge Limestone were analysed in the laboratory to determine

285 rock density using the displacement method. Repeated experimentation produced 
286 values of $2.4 \mathrm{~g} / \mathrm{cm}^{3}$. All tagged boulders were formed of the local Bembridge

287 Limestone.

288 The number of boulders selected for tagging was based on the ability to recover the 289 entire array within a single tidal window. With time allocated to setting up the survey 290 equipment and based on a working team of two persons we estimated it would be 291 possible to relocate between 50-55 boulders. Further consideration should be 292 reserved for tagging boulders in close proximity to one another. This relates to the 293 detection range of the RFID tags. For example, given an approximate tag detection 294 range of $0.75 \mathrm{~m}$, upon detection, any two or more tagged boulders within that range 295 may simultaneous transmit a tag ID code. These multiple transmissions create a 296 shadowing effect whereby both tags are activated yet only one code can be received 297 and displayed on the PDA (Lamarre et al., 2005; Dolphin et al., 2016; Chapuis et al., 298 2014). Therefore, it is suggested the minimum distance between tagged boulders 299 should exceed the mean detection range of the deployed tags.

300 In selecting boulders for tagging we aimed to represent a range of zones from both 301 sites as Naylor et al. (2016) identify the significance of morphological setting in 302 controlling boulder mobility. These locations also serve to establish a pre-transport 303 setting for each tagged boulder. The significance of the pre-transport setting is well 304 documented when used in conjunction with hydrodynamic equations to calculate the 305 magnitude of retrospective wave conditions responsible for boulder transport (Nott, 306 2003a; Spiske and Bahlburg, 2011; Nandasena et al, 2011b; Switzer and Burston, 307 2010). The boulder zones are summarised in Table 4. 
309 Owing to differences in local conditions it was not possible to maintain consistency of

310

311

312

313

314

315

316

317

318

319

320

321

322

323

324

325

326

327

328

329

330

331 selected boulders between sites, therefore some classifications are

underrepresented. This is due to the limited availability and accessibility of suitable

boulders to tag, e.g. the lower platform elevation at Black Rock restricts access to

boulders located seaward of the shore platform to only the lowest spring tides.

Finally, boulder selection was limited to those boulders that were deemed too large

to be moved by human intervention. All tagged boulders had an intermediate axis

$>0.25 \mathrm{~m}$, this restricted the agent of transport to wave activity alone.

\section{Field tag deployment}

The current literature refers to the deployment of RFID tags in gravel and cobbles only. There are no published accounts relating to the specific requirements for boulder tagging. We aim to address this with a detailed review of the tagging procedure demonstrating some key refinements that are required for boulder sized sediments.

Firstly, holes have to be drilled into boulders in the field to enable tag insertion. In preparation, drill tests were conducted within the laboratory on samples of the indigenous boulder rock type (Bembridge Limestone). These tests provided a valuable assessment on the operational capacity of the drill and the longevity of the battery and drill bits. Testing identified the necessity for a quality, industrial cordless drill and drill bits. We found the Makita 8391DWPQ 18v Ni-Cad Cordless Hammer Drill and DeWalt Extreme II 7mm drill bits performed particularly well.

Due to the number of boulders to be tagged in the field and based on the preceding laboratory tests a number of spare drill bits and a second drill battery were required 
332 together with a means of recharging drill batteries in the field. We achieved this using

333 a $12 \mathrm{~V}$ car battery connected to a power inverter which converts DC power to AC

334 enabling continued recharging of the spare drill battery whilst the other is in use. The

335 additional weight may prompt logistical considerations particularly where a study site

336 has restricted access and/or limited field assistance is available. Due to the

337 changeable nature of weather conditions at coastal locations we kept the recharging

338 equipment dry by securing it in a watertight receptacle.

339 The chosen location for tag insertion within the boulder is of great importance. To

340 accurately quantify boulder transport it is necessary to relocate and record the same

341 position on tagged boulders during each survey; we selected the tag insertion point

342 (TIP) for this purpose. Tag insertion in the $L / /$ plane should be avoided as in the

343 event of transport the boulder may be overturned on to the $L / /$ plane obstructing

344 access to the TIP. To increase the likelihood of accessing the TIP the tag should be

345 inserted in the $S$-axis parallel with the orientation of the $L$-axis (Figure 6). Knowing

346 the location of tag insertion makes identifying the TIP easier should the boulder

347 become colonised with algae and/or barnacles.

\section{$348 \quad$ Insert figure 6.}

349 Once a suitable TIP was identified a drill hole was made to the required depth with a

$3507 \mathrm{~mm}$ drill bit (hole depth and width required is dependent on tag size). Excess dust

351 was expelled from the hole prior to tag insertion to create a dust-free surface. A

352 waterproof, silicon-based sealant (Evo-Stik Wet grab) was injected into the hole,

353 filling to approximately $75 \%$. The pre-prepared sleeved tag was inserted with the

354 copper coils orientated towards the drilled exit hole. This was based on the

355 increased read range of the tags positioned in this manner, as identified in Table 2. 
356 Once embedded any excess sealant was removed. A further protective seal was

357 applied using Plastic Padding Marine Epoxy creating an additional barrier to prevent

358 the ingress of seawater (R. Brayne, $8^{\text {th }}$ April 2014, pers. comm.). Prior to application

359 the epoxy should be mixed as per the manufacturer's instruction. Curing time varies

360 between products and depending on ambient temperature meaning incoming tides

361 may not allow for the necessary curing times. Hence, it is important to use an epoxy

362 resin that can, if necessary, be applied and cured underwater. Once embedded it is

363 advisable to ensure the tag is detectable and the unique ID code can be transmitted

364 from within the boulder prior to moving on to the next tag insertion. We suggest

365 undertaking laboratory trials of the adhesive and protective properties of the chosen

366 sealant and epoxy prior to full-scale field deployment.

367 Existing research has indicated that wave activity is capable of flipping, or

368 overturning a range of boulder sizes (Sousa 1979; Noormets et al., 2004; Imamura

369 et al., 2008). Such events can be inferred by algal growth on a boulders underside

370 (Knight et al., 2009), by the presence of biotic indicators (Mastronuzzi and Sansò

3712004 ) or using comparative photographic evidence (Cox et al., 2018). The ability to

372 identify overturning during entrainment provides a useful insight to the mode of

373 transport. To establish when incidents of overturning occur we suggest drilling a

374 secondary orientation hole, approximately $0.01 \mathrm{~m}$ deep above the TIP. This identifies

375 the upward orientation of the boulder at the time of tag deployment. Any relocated

376 boulder found with the orientation hole below the TIP can unequivocally be identified

377 as being overturned during transport.

378 Recording tagged boulder characteristics 
379 On completion of the tagging procedure a series of boulder characteristics were 380 noted, as described in Table 5.

$381 \quad$ Insert table 5.

382 Under favourable conditions the tag insertion procedure and collation of 383 characteristics took approximately 5-8 minutes per boulder.

\section{$384 \quad$ Insert figure 7.}

\section{Tag retrieval surveys}

386 The frequency of the retrieval surveys was dictated by a number of factors including 387 favourable tides, the occurrence of storm activity and availability of field assistance. 388 As part of this study fifteen surveys were undertaken between July 2015 and May 3892017 (seven at Bembridge Ledge and eight at Black Rock). Accessibility to tagged 390 boulders limited surveys to periods of low water only.

391 To date RFID studies relocate tagged sediment by systematically scanning the 392 survey area with the pole antenna in the same manner as a standard metal detector 393 (Nichols, 2004; Dolphin et al., 2016). To ensure a more productive use of time in the 394 field we utilised the 'stake-out survey' functionality of the Topcon DGNSS. This 395 allowed us to upload boulder coordinate data as recorded on the preceding survey to 396 the DGNSS handheld interface. By accessing the uploaded data points in the field 397 we were directed to the previously recorded coordinate of the selected boulder as 398 indicated on the interface display screen. If the boulder was not relocated at that 399 location the RFID detection equipment was used to scan the surrounding area until it 400 was found. Once relocated, boulder characteristics 3-8 as described in Table 5 were 401 documented. 
402 At Bembridge Ledge we found that tagged boulders deposited towards the beach toe

403 were subject to burial from the seasonal accretion of sediment. Despite being

404 obscured from view we were able to relocate buried boulders using the RFID

405 equipment to depths of up to $0.4 \mathrm{~m}$. Upon relocation, the overlaying sediment was

406 removed and the TIP recorded (Figure 8). Once the boulder location was recorded

407 the excavated sediment was replaced.

$408 \quad$ Insert figure 8.

409 Field survey equipment

410 In order to detect boulder movement in the centimetre range a DGNSS setup was

411 required to provide a high survey resolution. Recreational GPS receivers or mobile

412 phones with GNSS capabilities do not offer this level of precision (Schaefer and

413 Woodyer, 2015). DGNSS uses static base stations with known positions to correct

414 for the biases that cause GNSS errors (van Sickle, 2008; Kaplan and Hegarty,

415 2005). Boulder relocation surveys were conducted using a Topcon Hiper V in Real-

416 Time Kinematic (RTK) mode. This uses a local base station that sends out a

417 correction signal in real time to a mobile GNSS receiver (rover), providing a relative

418 horizontal accuracy of 5mm, +/-0.5ppm, (Topcon, 2017).

419 Defining boulder transport

420 In coarse sediment transport studies the distinction between entrainment and

421 transport is frequently unclear (Naylor et al., 2016). By establishing a displacement

422 threshold we are able to discriminate between the two, making it possible to

423 establish when boulder transport has, or has not, occurred. Previous studies have

424 monitored block displacement by embedding datalogging tri-axial accelerometers 
425 within clasts (Stephenson and Abazovic, 2016 and Brayne, 2015). The loggers

426 record three-dimensional tilt and acceleration of the clast allowing the user to

427 differentiate between incremental entrainment, such as motion about a fixed point,

428 and major movement in a specific direction, akin to transport (Brayne, 2015).

429 Alternative methods have been employed that avoid the use of loggers, the cost of

430 which can be prohibitive. Naylor et al. (2016) define transport whereby the distance

431 moved and the combined root mean squared (RMSE) exceeds half the long axis

432 length of a given clast, the RMSE being calculated from GPS, rover pole position

433 and clast re-measurement error. This method was adopted as they were unable to

434 re-record the same point on individual boulders. Unlike the aforementioned study we

435 have a fixed point (the TIP) from which the boulder location can repeatedly be re-

436 recorded. Therefore, in defining transport we combine the error from the relative

437 accuracy of the DGNSS, the setup of the base station and the RMSE of re-surveying

438 the TIP. The RMSE is based on recording four fixed points (two at each site) with the

439 DGNSS as part of the field surveys; 30 measurements were recorded giving a

440 RMSE of $+/-0.03 m$ in the horizontal and vertical axis, although maximum values of

$4410.08 \mathrm{~m}$ were recorded. Based on the cumulative error values we conservatively set

442 the horizontal and vertical error at $0.1 \mathrm{~m}$. This provides an entrainment/transport

443 threshold whereby any movement calculated via the python script exceeding $0.1 \mathrm{~m}$ is

444 defined as transported. Conversely, values below $0.1 \mathrm{~m}$ are deemed to be entrained

445 and are not incorporated into any transport distance values.

446 The transport distance of the tagged boulders is calculated from the coordinate data

447 from each survey which is input to the python script. The summed values for each

448 boulder across all surveys we term the individual boulder transport distance (IBTD). 
449 The summed IBTD values for each survey we term the cumulative transport distance 450 (CTD), Table 6.

\section{$451 \quad$ RESULTS}

452 We report a range of metrics derived from the RFID boulder coordinate data

453 obtained during successive field surveys. The data presented herein provides an

454 insight to the feasibility of the methodology. Additionally, we demonstrate the

455 capability of the method by presenting examples of mobility that occurred during the

456 field study which further augment the use of RFID's in boulder transport monitoring.

\section{Recovery rates}

458 A total of 15 field surveys (Bembridge Ledge, 7 and Black Rock, 8) were conducted

459 between July 2015 and May 2017 to relocate tagged boulders across the two study

460 sites. We achieved a mean tag recovery rate of $91 \%$, cumulatively recovering 714 of

461 a possible 782 tagged boulders across all surveys at the two sites. Minimum /

462 maximum tag recovery rates were $68 \%$ / 100\% at Bembridge Ledge, and $81 \%$ /

$463100 \%$ at Black Rock (Table 6). Reduced tag recovery was attributed to the seasonal

464 accretion of sediment leading to boulder burial at Bembridge Ledge and

465 unfavourable and unsafe tidal conditions at Black Rock.

\section{Boulder transport}

467 Once relocated, RFID tag locations were recorded using DGNSS survey equipment.

468 Successive surveys created a series of coordinates for each of the 104 tagged

469 boulders. The python script automatically processed the recorded boulder coordinate

470 data to produce a series of inter-survey transport statistics, including the IBTD (Table

$4716)$. We identified $63 \%$ of the 104 tagged boulders were transported at least once 
$472(n=66 / 104)$, i.e. were mobile over distances exceeding $0.1 \mathrm{~m}$. Over the study we

473 recorded 164 individual transport events culminating in a total boulder transport

474 distance of $184.6 \mathrm{~m}$ across the two sites.

475 At Bembridge Ledge 94 transport events were documented amounting to a total CTD 476 of $117.0 \mathrm{~m}$. Of that figure, the highest percentage of mobility $(42 \% / 49.3 \mathrm{~m})$ occurred 477 between July 2015 and $3^{\text {rd }}$ February 2016. Between these survey dates increased 478 wave activity recorded by the CCO wave buoy occurred between $30^{\text {th }}$ December 4792015 and $7^{\text {th }}$ January 2016. Peak storm activity occurred on $3^{\text {rd }}$ January 2016 , when 480 maximum significant wave heights $\left(\mathrm{H}_{\mathrm{s}}\right)$ of $3.3 \mathrm{~m}$ and maximum wave height $\left(\mathrm{H}_{\max }\right)$ of $4815.4 \mathrm{~m}$ with a peak wave period of 7.7 seconds were recorded (CCO, 2017b). Surveys 482 at Black Rock on $3^{\text {rd }}$ December 2015 and $6^{\text {th }}$ January 2016 identify boulder transport 483 amounting to $6.9 \mathrm{~m}$ during this period which coincides with the increased wave 484 activity recorded on the $3^{\text {rd }}$ January 2016. Interestingly, peak storm waves occurred 485 between low water and 2 hours thereafter. The most significant transport distances 486 were recorded in boulders located around low water on the exposed shore platform. 487 This suggests boulder transport is influenced not only by storm wave activity but by 488 tidal state at the time of peak storm intensity which determines where on the profile 489 storm energy is focused. This corresponds with comparable work on the role of tidal 490 state in beach morphodynamics (Kroon and Masselink, 2002; Castelle et al., 2015; 491 Masselink et al., 2016b).

492 At Black Rock, 70 transport events were recorded during the study amounting to a 493 total CTD of $67.6 \mathrm{~m}$. Of that figure the highest percentage $(41 \% / 27.7 \mathrm{~m})$ occurred 494 between surveys conducted on $19^{\text {th }}$ February and $31^{\text {st }}$ May 2016 coinciding with 495 increased wave energy associated with Storm Katie (28 ${ }^{\text {th }}$ March 2016). For a period 496 of 6.5 hours $H_{s}$ values exceeded $2.0 \mathrm{~m}$, with a maximum $\mathrm{H}_{\mathrm{s}}$ value of $4.2 \mathrm{~m}$ and $\mathrm{H}_{\max }$ of 
$4976.6 \mathrm{~m}$ being recorded; wave periods ranged between 6.3 - 10 seconds (CCO, 2017b).

498 Conversely, surveys at Bembridge Ledge encompassing this period ( $17^{\text {th }}$ February -

$4991^{\text {st }}$ April 2016) identified 13 incidents of mobility covering a distance of $6.2 \mathrm{~m}$, only $5 \%$

500 of the total CTD at the site. This disparity is thought to be the result of the southerly

501 wind and wave direction during the storm event (mean: $170^{\circ}$ ). The southerly aspect

502 of Black Rock being more exposed to the storm opposed to the north-easterly

503 orientation of Bembridge Ledge which was afforded a degree of protection.

504 Incidents of mobility - Bembridge Ledge

505 At Bembridge Ledge $76 \%(n=38 / 50)$ of the tagged boulders were mobile at least

506 once. IBTD values ranged between $0.1 \mathrm{~m}$ and $21.5 \mathrm{~m}$, mobile boulder mass ranged

507 between an estimated $0.1 \mathrm{t}-1.3 \mathrm{t}$ (Table 6).

508 Transport was documented in a boulder weighing approximately $1.2 \mathrm{t}$ that had

509 become detached from the platform edge yet remained in-situ (Figure 9, inset). It

510 was surveyed on $3^{\text {rd }}$ February 2016 however, the subsequent survey on $17^{\text {th }}$

511 February 2016 identified transport of $7.2 \mathrm{~m}$ landward of its previous location (Figure

512 9). Whilst mobile the boulder was overturned prior to deposition at the foot of the

513 shingle beach where the slope angle increases. Overturning was identified by algal

514 growth on the underside of the boulder and the orientation hole being located below

515 the TIP, as opposed to above, as at the time of tag deployment. The transport event

516 described coincided with increased wave activity associated with Storm Imogen ( $8^{\text {th }}$

517 February 2016) when $\mathrm{H}_{\mathrm{s}}$ of $2.5 \mathrm{~m}$ were recorded, with a wave period of 7 seconds.

518 Further storm induced transport totalling $2.9 \mathrm{~m}$ was recorded for this clast amounting

519 to an IBTD of $10.1 \mathrm{~m}$ over the 22 month monitoring period.

$520 \quad$ Insert figure 9. 
521 The coordinate data attributed to the aforementioned boulder was used to create a

522 visual interpretation in ArcGIS which documents spatial and temporal boulder

523 mobility. This was generated from the python script (Figure 10).

524 Insert figure 10.

525 Incidents of mobility - Black Rock

526 At Black Rock $52 \%(n=28 / 54)$ of the tagged boulders were mobile at least once.

527 IBTD values ranged between $0.1 \mathrm{~m}$ and $10.1 \mathrm{~m}$. Mobile boulder mass ranged

528 between an estimated $0.1 \mathrm{t}-11.9 \mathrm{t}$ (Table 6).

529 A boulder located $20 \mathrm{~m}$ from the platform edge weighing an estimated $5 \mathrm{t}$ was tagged

530 at the commencement of the field campaign. Notably, the clast was not visible on the

531 CCO aerial imagery captured in August 2013 and is thought to have been displaced

532 and deposited during the winter storms of $2013-2014$. The boulder location was

533 recorded on $19^{\text {th }}$ February 2016 identified by the circle in Figure 11a. It was

534 relocated on $31^{\text {st }}$ May 2016 having been transported $6.4 \mathrm{~m}$ landward and overturned

535 prior to deposition, imbricate against an extensive boulder ridge. The transport event

536 described is thought to be attributed to Storm Katie (27 $7^{\text {th }}$ March 2016) when

537 maximum $\mathrm{H}_{\mathrm{s}}$ was recorded as $4.2 \mathrm{~m}$, with a maximum wave period of 12.5 seconds.

538 Further transport, post Storm Katie, was attributed to wave activity associated with

539 Storm Angus on $20^{\text {th }}$ November 2016, maximum $\mathrm{H}_{\mathrm{s}}$ of $4.0 \mathrm{~m}$ and wave period of 6.8

540 seconds (CCO, 2017b) whereby the boulder was overturned $180^{\circ}$ and deposited

$5412.5 \mathrm{~m}$ seawards from its previously recorded location, circle in Figure 11b.

542 Insert figure 11. 
543 In both instances boulder transport was impeded by topographic (raised shingle

544 beach at Bembridge Ledge) and morphological (boulder ridge at Black Rock)

545 features. This emphasises the significance of localised morphology in restricting and

546 controlling boulder transport potential affirming the findings of Pérez-Alberti \&

547 Trenhaile (2015b) and Naylor et al. (2016) who suggest such landforms exert a

548 degree of control over boulder transport potential.

$549 \quad$ Insert table 6.

550 DISCUSSION

551 Our proposed methodology, employing RFID tags embedded in an array of boulder-

552 sized clasts has enabled us to identify and accurately quantify boulder mobility as a

553 result of contemporary storm activity. Upon completion of the study we achieved a

554 mean tracer recovery rate of $86 \%$ at Bembridge Ledge and 95\% Black Rock. Field

555 data identified periodic boulder mobility resulting from contemporary storm activity

556 despite the locations relatively low to moderate wave exposure in comparison to

557 previously studied boulder transport sites.

\section{Boulder transport}

559 By establishing an entrainment/transport threshold we can reliably identify transport

560 events and differentiate them from entrainment. Using the TIP we are able to

561 relocate and record a specific point on each tagged boulder. This allows us to apply

562 a universal displacement threshold that is applicable to each tagged boulder

563 regardless of size. This is advantageous over alternative methods applied by Naylor

564 et al. (2016) as it provides greater precision, particularly for coarser sized clasts,

565 when defining the distance over which a boulder has been transported. 
566 The calculated transport data identified Bembridge Ledge exceeded Black Rock in

567 terms of the number of transport events (94 / 70) and the distance over which those

568 mobile boulders were displaced $(117.0 \mathrm{~m} / 67.6 \mathrm{~m})$. This is, in part, due to the different

569 lithologies between the sites. The boulder producing limestone outcrops differ in

570 terms of the extent of jointing and bed thickness. Owing to the thinner, more

571 discontinuous lithology at Bembridge Ledge smaller, tabular boulders are produced

572 which have a lower transport threshold than the larger boulders produced at Black

573 Rock, corroborating the significance of localised geology on boulder production

574 (Stephenson and Naylor, 2011). In addition, obstructions including a greater number

575 of detached clasts, irregular substrate and an extensive boulder ridge impede

576 landward transport, particularly at Black Rock, resulting in a higher number of

577 topographically constrained deposits (Trenhaile, 2016). The substrate varies

578 between, and within sites. Bembridge Ledge is generally characterised by a

579 smoother platform surface which promotes clast mobility. Comparatively, Black Rock

580 has a larger area of pitted terrain which traps boulders impeding landward transport.

581 The close proximity of the recorded wave data to the study sites allows us to infer

582 the likely agent of transport and identify the wave conditions under which boulder

583 mobility occured. Furthermore, by incorporating a boulder orientation indicator we

584 were able to identify 22 incidents of boulders being overturned during transport, 11 at

585 each site; $68 \%$ of these occurring between July 2015 and $19^{\text {th }}$ February 2016 . This

586 constitutes overturning in $13 \%$ of the recorded movements suggesting it is significant

587 but relatively infrequent. Understanding how boulders respond to hydrodynamic

588 conditions under which they have been transported is of considerable significance

589 when applying numerical models to hindcast wave characteristics such as height 
590 and/or velocity (Goto et al., 2009; Nandasena et al., 2011a; Nandasena et al., 591 2011b).

\section{Addressing limitations and uncertainties}

593 Prior to the commencement of the study we had reservations regarding the suitability 594 of the RFID tagging technology to monitor boulder transport. Paris et al. (2011) and 595 Naylor et al. (2016) describe a number of potential issues with the technique which 596 we are now able to allay.

597 (1) Would RFID tags withstand the harsh coastal conditions and remain operational 598 throughout the study?

599 Despite the successful use of RFID tags in long term coastal sediment monitoring 600 (Allan et al., 2006; Dolphin et al., 2016), and our pre-deployment sealant checks, 601 concerns remained regarding how the unfavourable conditions and prolonged 602 exposure may affect tag operation and/or retention within the boulder. However, we 603 experienced no issues with tag functionality during the survey period. With the 604 exception of 5 lost tags, which we were able to replace, the remaining 99 tags 605 remained fully operational and traceable throughout the study. Tag loss was 606 attributed to poor sealant adhesion, perhaps as a result of insufficient curing times. 607 We have since trialled a vinylester chemical anchor resin (ProVenture PRO V200) 608 opposed to the widely available silicone sealant. The resin has performed well in 609 laboratory tests involving wetting and drying in saltwater solutions and has since 610 been deployed in the field to replace the lost tags and to date has functioned well.

611 (2) How effective would the RFID equipment be in relocating tagged boulders, 612 particularly buried clasts? 
613 The RFID equipment performed well in the field. Throughout the survey period it was

614 apparent that concerns over relocating tagged boulders related to environmental

615 factors beyond our control rather than limitations with the equipment and/or

616 methodology. At Bembridge Ledge we frequently encountered incidents of burial

617 following the accretion of sand and shingle. However, we were able to detect buried

618 clasts up to a depth of $0.4 \mathrm{~m}$. Owing to the extent of burial and time constraints it was

619 not always possible to excavate the overlying sediment; additional manpower may

620 have offered increased opportunity to excavate buried clasts. Black Rock recovery

621 rates were reduced as a result of unfavourable tidal states due to the low elevation of

622 an area of the field site in proximity to mean low water. On occasion this created

623 hazardous surveying conditions rendering a number of boulders inaccessible.

624 Greater consideration of tagged boulder location relative to mean low water may

625 have reduced the likelihood of such an occurrence and improved rates of tag

626 recovery.

627 (3) Would clast breakdown impact on recovery rates?

628 We documented clast breakage in one of the 104 tagged boulders. The limited

629 mobility of the clast (IBTD $-0.7 \mathrm{~m}$ ) suggests breakdown was not attributed to impact

630 during transport but due to the inherent weaknesses within the boulder; breakdown

631 occurred along a number of structural joints.

632 There was no evidence to suggest drilling for tag insertion initiated boulder

633 breakdown, as encountered by Cassel et al. (2017) as we took care to avoid drilling

634 through any discontinuity planes. This suggests clasts exhibiting structural joints

635 should be avoided when selecting boulders to tag. 
636 (4) Would it be possible to relocate and document the tagged boulders within a 637 single tidal window?

638 The 'stake-out survey' functionality on the DGNSS hastened the boulder recovery 639 process allowing us to maximising the time available in the field. It enabled us to 640 recover tagged boulders within our $0.1 \mathrm{~km}^{2}$ survey area with greater ease than 641 adopting a random search approach. Had we not incorporated this feature into the 642 methodology our ability to relocate tagged boulders would have been compromised.

643 The overall performance of RFID tagged boulders has been encouraging. Coupled 644 with our proposed methodology they have provided new data on the extent to which 645 boulders are transported in the intertidal zone by contemporary storm events.

646 Additionally, they have provided an insight to the mode of transport when displaced

647 through the addition of an orientation indicator. The success of this deployment has

648 enabled the study to continue into a third year. It is anticipated that with regular

649 monitoring and maintenance of the tagged boulder array the study can continue

650 indefinitely ensuring this will be the first known long-term study using RFID tagging to 651 quantify boulder transport resulting from storm activity.

\section{CONCLUSION}

653 Drawing upon previous RFID transport studies and the findings presented here we 654 assert that RFID technology and our methodology are an efficient and effective 655 means of monitoring and quantifying the response of intertidal boulders to 656 contemporary storm events. Using RFID tagged boulders we have been able to 657 identify transport episodes resulting from periods of increased wave activity. The 658 collated data has enabled the production of vector diagrams via a python script 659 which detail the distance and direction of boulder transport. 
660 The existing literature relating to boulder transport focuses on coastlines subjected to 661 considerable storm induced wave energy (Cox et al., 2012; Etienne and Paris, 2010;

662 Goto et al., 2011; Knight and Burningham, 2011). Significantly, the RFID

663 methodology has enabled us to identify boulder detachment, transport and

664 overturning at a relatively sheltered, fetch limited intertidal site subjected to moderate 665 wave conditions. This demonstrates that contemporary storm events have a far 666 greater ability to mobilise boulders than had previously been realised.

667 To further augment the methodology we recommend additional deployments in more 668 exposed settings with larger boulders subjected to higher wave energy regimes.

669 Furthermore, the methodology could be extended to use in the supratidal zone for 670 the long-term monitoring of cliff-top boulder deposits such as those identified by 671 Autret et al. (2018) and Cox et al. (2018). This would provide greater understanding 672 on the impact, ability and associated risk of extreme wave events to mobilise 673 boulders which may require a reassessment of our current understanding of storm 674 wave hydrodynamics.

675 The methodology can also be utilised with emerging technologies, such as UAV 676 monitoring (Pérez-Alberti \& Trenhaile, 2015a, 2015b; Biolchi et al., 2016) to provide 677 greater spatial resolution on the mechanisms that facilitate the transport of intertidal 678 boulders. Furthermore, deployment in coastal revetment blocks could help mitigate 679 against damage or loss to coastal defence engineering works.

680 This study has highlighted the feasibility of both the RFID technology and our 681 methodology to provide coastal researchers with a new field technique to accurately 682 assess boulder mobility. By adopting the methodology the opportunity exists for 683 researchers to clearly define and quantify boulder transport pathways and provide 
684 clarity on the impacts and responses of contemporary storm events in shaping rocky
685 coastal landforms.

686 Footnote - Permissions

687 Under the Marine Licensing (Exempted Activities) Order 2011 the deployment of

688 scientific equipment, including sediment tracers such as RFID's is deemed a

689 Category 2 exemption and may not require a marine license (Marine Licensing

690 Order, 2011). However, owing to the sensitive nature of the study site we obtained

691 an exemption from the Marine Management Organisation (MMO) and sort approval

692 from Natural England prior to tag deployment.

\section{Acknowledgements}

694 The authors acknowledge the British Society of Geomorphology and the Royal

695 Geographical Society who assisted with funding the field work element of the study.

696 The authors wish to extend their gratitude to those that provided invaluable field

697 assistance, without their input the research would not have been possible; Tom

698 Thorp, Liam Matear, Louise Richards, Elizabeth Inwards, Kathrine Bell, Lauren

699 Knight, Paul Carter, Paul Weber and Alex Hilawi. We are also sincerely grateful to

700 the anonymous reviewer's for their insightful comments and suggestions which have

701 greatly improved this paper.

702

703 References

704 Allan JC, Hart R, Tranquili JV. 2006. The use of Passive Integrated Transponder

705 (PIT) tags to trace cobble transport in a mixed sand-and-gravel beach on the high- 
706 energy Oregon coast, USA. Marine Geology 232: 63-86. DOI:

707 10.1016/j.margeo.2006.07.005

708 Aluf O. 2017. RFID Antennas Systems Descriptions and Analysis. In Microwave RF

709 Antennas and Circuits 2017: 1-15. Springer International Publishing. DOI:

710 10.1007/978-3-319-45427-6_1

711 Armenteros I, Daley B. 1998. Pedogenic modification and structure evolution in

712 palustrine facies as exemplified by the Bembridge Limestone (Late Eocene) of the

713 Isle of Wight, southern England. Sedimentary Geology 119(3): 275-95. DOI:

714 10.1016/S0037-0738(98)00067-0

715 Autret R, Dodet G, Fichaut B, Suanez S, David L, Leckler F, Ardhuin F, Ammann J,

716 Grandjean P, Allemand P, Filipot JF. 2016. A comprehensive hydro-geomorphic

717 study of cliff-top storm deposits on Banneg Island during winter 2013-2014. Marine

718 Geology 382: 37-55. DOI: 10.1016/j.margeo.2016.09.014

719 Autret R, Dodet G, Suanez S, Roudaut G and Fichaut B. 2018. Long-term variability

720 of supratidal coastal boulder activation in Brittany (France). Geomorphology 304:

721 184-200. DOI:org/10.1016/j.geomorph.2017.12.028

722 Barbano, M. S., Pirrotta, C., \& Gerardi, F. (2010). Large boulders along the south-

723 eastern Ionian coast of Sicily: storm or tsunami deposits? Marine Geology, 275(1),

$724 \quad 140-154$.

725 Barbano MS, Pirrotta C, Gerardi F. 2010. Large boulders along the south-eastern

726 Ionian coast of Sicily: storm or tsunami deposits? Marine Geology 275(1) :140-54.

727 DOI: 10.1016/j.margeo.2010.05.005 
728 Beniston M, Stephenson DB, Christensen OB, Ferro CA, Frei C, Goyette S,

729 Halsnaes K, Holt T, Jylhä K, Koffi B, Palutikof J. 2007. Future extreme events in

730 European climate: an exploration of regional climate model projections. Climatic

731 Change 81(1):71-95. DOI: 10.1007/s10584-006-9226-z

732 Biolchi S, Furlani S, Antonioli F, Baldassini N, Deguara JC, Devoto S, Di Stefano A,

733 Evans J, Gambin T, Gauci R, Mastronuzzi G. 2016. Boulder accumulations related to

734 extreme wave events on the eastern coast of Malta. Natural Hazards and Earth

735 System Sciences 16: 737-56.

736 Black KS, Athey S, Wilson P, Evans D. 2007. The use of particle tracking in

737 sediment transport studies: a review. Geological Society, London, Special

738 Publications 274(1): 73-91. DOI: 10.1144/GSL.SP.2007.274.01.09

739 Blair TC, McPherson JG. 1999. Grain-size and textural classification of coarse

740 sedimentary particles. Journal of Sedimentary Research 69(1): 6-19.

741 Bray MJ, Workman M, Smith J, Pope D. 1996. Field measurements of shingle

742 transport using electronic tracers. In Proc. 31st MAFF Conf. River and Coastal

743 Engineers 1996 (pp. 10-4).

764 Brayne RP. 2015. The Relationship between Nearshore Wave Conditions and

765 Coarse Clastic Beach Dynamics. Unpublished PhD Thesis, Exeter University.

766 Cassel M, Piégay H, Lavé J. 2017. Effects of transport and insertion of radio

767 frequency identification (RFID) transponders on resistance and shape of natural and

768 synthetic pebbles: applications for riverine and coastal bedload tracking. Earth

769 Surface Processes and Landforms 42(3): 399-413. DOI: 10.1002/esp.3989 
770 Castelle B, Marieu V, Bujan S, Splinter KD, Robinet A, Sénéchal N, Ferreira S. 2015.

771 Impact of the winter 2013-2014 series of severe Western Europe storms on a

772 double-barred sandy coast: Beach and dune erosion and megacusp

773 embayments. Geomorphology, 238, 135-148. DOI: 10.1016/j.geomorph.2015.03.006

774 Channel Coast Observatory, CCO. 2017a. Regional Coastal Monitoring Programmes

775 Sandown Bay. [Online]. Available at:

776 https://www.channelcoast.org/data_management/real_time_data/charts/?chart=80\&t

777 ab=info\&disp_option= [Accessed: 20 May 2017].

778 Channel Coast Observatory, CCO. 2017b. Data management catalogue. [Online].

779 Available at:

780 http://www.channelcoast.org/data_management/online_data_catalogue/metadata/se 781 arch/index2.php [Accessed: 28 July 2017].

782 Chapuis M, Bright CJ, Hufnagel J, MacVicar B. 2014. Detection ranges and

783 uncertainty of passive Radio Frequency Identification (RFID) transponders for

784 sediment tracking in gravel rivers and coastal environments. Earth Surface

785 Processes and Landforms 39(15): 2109-20. DOI: 10.1002/esp.3620

786 Ciavola P, Castiglione E. 2009. Sediment dynamics of mixed sand and gravel

787 beaches at short time-scales. Journal of Coastal Research. Special Issue No. 56.

788 Proceedings of the 10th International Coastal Symposium 2009, Vol. II: 1751-1755.

789 Cox R, Zentner DB, Kirchner BJ, Cook MS. 2012. Boulder ridges on the Aran Islands

790 (Ireland): recent movements caused by storm waves, not tsunamis. The Journal of

791 Geology 120(3): 249-272. DOI: https://doi.org/10.1086/664787 
792 Cox R, Jahn KL, Watkins OG, Cox P. 2018. Extraordinary boulder transport by storm 793 waves (West of Ireland, winter 2013-2014), and criteria for analysing coastal boulder 794 deposits. Earth-Science Reviews 177: 623-636. DOI: 0.1016/j.earscirev.2017.12.014

795 Curtiss GM, Osborne PD, Horner-Devine AR. 2009. Seasonal patterns of coarse 796 sediment transport on a mixed sand and gravel beach due to vessel wakes, wind 797 waves, and tidal currents. Marine Geology 259(1): 73-85. DOI:

$798 \quad$ 10.1016/j.margeo.2008.12.009

799 Daley B, Edwards N. 1990. The Bembridge Limestone (Late Eocene), Isle of Wight, 800 southern England: a stratigraphical revision. Tertiary Research12(2): 51-64.

801 Dickson ME, Kench PS, Kantor MS. 2011. Longshore transport of cobbles on a 802 mixed sand and gravel beach, southern Hawke Bay, New Zealand. Marine Geology 803 287(1): 31-42. DOI: 10.1016/j.margeo.2011.06.009

804 Dolphin T, Lee J, Phillips R, Taylor CJ, Dyer KR. 2016. Velocity of RFID Tagged 805 Gravel in a Non-uniform Longshore Transport System. Journal of Coastal Research 806 75(sp1): 363-7. DOI: 10.2112/SI75-073.1

807 Engel M, May SM. 2012. Bonaire's boulder fields revisited: evidence for Holocene 808 tsunami impact on the Leeward Antilles. Quaternary Science Reviews 54:126-141. 809 DOI: 10.1016/j.quascirev.2011.12.011

810 Easterling DR, Meehl GA, Parmesan C, Changnon SA, Karl TR, Mearns LO. 2000.

811 Climate extremes: observations, modeling, and impacts. Science, 289 (5487), 2068812 2074. DOI: 10.1126/science.289.5487.2068 
813 Etienne S, Buckley M, Paris R, Nandasena AK, Clark K, Strotz L, Chagué-Goff C,

814 Goff J, Richmond B. 2011. The use of boulders for characterising past tsunamis:

815 lessons from the 2004 Indian Ocean and 2009 South Pacific tsunamis. Earth-

816 Science Reviews 107(1): 76-90. DOI: 10.1016/j.earscirev.2010.12.006

817 Etienne S, Paris R. 2010. Boulder accumulations related to storms on the south

818 coast of the Reykjanes Peninsula (Iceland). Geomorphology 114(1): 55-70. DOI:

819 10.1016/j.geomorph.2009.02.008

820 Fichaut B, Suanez S. 2011. Quarrying, transport and deposition of cliff-top storm

821 deposits during extreme events: Banneg Island, Brittany. Marine Geology 283(1): 36-

822 55. DOI: 10.1016/j.margeo.2010.11.003

823 Goto K, Okada K, Imamura F. 2009. Characteristics and hydrodynamics of boulders

824 transported by storm waves at Kudaka Island, Japan. Marine Geology 262(1): 14-24.

825 DOI: 10.1016/j.margeo.2009.03.001

826 Goto K, Miyagi K, Kawana T, Takahashi J, Imamura F. 2011. Emplacement and

827 movement of boulders by known storm waves - field evidence from the Okinawa

828 Islands, Japan. Marine Geology 283(1): 66-78. DOI: 10.1016/j.margeo.2010.09.007

829 Goto K, Sugawara D, Ikema S, Miyagi T. 2012. Sedimentary processes associated

830 with sand and boulder deposits formed by the 2011 Tohoku-oki tsunami at

831 Sabusawa Island, Japan. Sedimentary Geology 282: 188-98. DOI:

$832 \quad$ 10.1016/j.sedgeo.2012.03.017 
833 Hall AM. 2011. Storm wave currents, boulder movement and shore platform

834 development: a case study from East Lothian, Scotland. Marine Geology 283(1): 98-

835 105. DOI: 10.1016/j.margeo.2010.10.024

836 Han M, Yang DY, Yu J, Kim JW. 2017. Typhoon Impact on a Pure Gravel Beach as

837 Assessed through Gravel Movement and Topographic Change at Yeocha Beach,

838 South Coast of Korea. Journal of Coastal Research 33(4): 889 - 906. DOI:

839 10.2112/JCOASTRES-D-16-00104.1

840 Imamura F, Goto K, Ohkubo S. 2008. A numerical model for the transport of a

841 boulder by tsunami. Journal of Geophysical Research: Oceans, 113(C1). DOI:

$84210.1029 / 2007 J C 004170$

843 Jolliffe IP. 1964. An experiment designed to compare the relative rates of movement 844 of different sizes of beach pebble. Proceedings of the Geologists' Association 75(1):

845 77-86. DOI: 10.1016/S0016-7878(64)80012-2

846 Kaplan E, Hegarty C. 2005. Understanding GPS: principles and applications. Artech 847 House.

848 Kidson C, Carr AP, Smith DB. 1958. Further experiments using radioactive methods 849 to detect the movement of shingle over the sea bed and alongshore. The 850 Geographical Journal 124(2):210-8. DOI: 10.2307/1790248

851 Knight J, Burningham H. 2011. Boulder dynamics on an Atlantic-facing rock 852 coastline, northwest Ireland. Marine Geology, 283 (1-4). 56-65. 
853 Knight J, Burningham H, Barrett-Mold C. 2009. The geomorphology and controls on

854 development of a boulder-strewn rock platform, NW Ireland. Journal of Coastal

855 Research 1:1646-1650.

856 Kroon A, Masselink G. 2002. Morphodynamics of intertidal bar morphology on a

857 macrotidal beach under low-energy wave conditions, North Lincolnshire,

858 England. Marine Geology, 190(3-4), 591-608. DOI: 10.1016/S0025-3227(02)00475-9

859 Lamarre H, MacVicar B, Roy AG. 2005. Using passive integrated transponder (PIT)

860 tags to investigate sediment transport in gravel-bed rivers. Journal of Sedimentary

861 Research 75(4): 736-741. DOI: 10.2110/jsr.2005.059

862 Lee MW, Bray M, Workman M, Collins MB, Pope D. 2000. Coastal shingle tracing: a 863 case study using the Electronic Tracer System (ETS). Tracers in Geomorphology: 864 413-35.

865 Lee MW, Sear DA, Atkinson PM, Collins MB, Oakey RJ. 2007. Number of tracers 866 required for the measurement of longshore transport distance on a shingle beach. 867 Marine Geology 240(1): 57-63. DOI: 10.1016/j.margeo.2007.02.010

868 Liébault F, Bellot H, Chapuis M, Klotz S, Deschâtres M. 2012. Bedload tracing in a 869 high-sediment-load mountain stream. Earth Surface Processes and Landforms 870 37(4): 385-99. DOI: 10.1002/esp.2245

871 Marine Licensing (Exempted Activities) Order 2011 (SI 2011/No. 409). Available at: 872 http://www.legislation.gov.uk/uksi/2011/409/part/3/made [Accessed 2nd November, 873 2017]. 
874 Masselink G, Castelle B, Scott T, Dodet G, Suanez S, Jackson D, Floc'h F. $2016 a$.

875 Extreme wave activity during 2013/2014 winter and morphological impacts along the

876 Atlantic coast of Europe. Geophysical Research Letters 43(5): 2135-43. DOI:

$87710.1002 / 2015 G L 067492$

878 Masselink G, Scott T, Poate T, Russell P, Davidson M, Conley D. 2016b. The

879 extreme 2013/2014 winter storms: hydrodynamic forcing and coastal response along

880 the southwest coast of England. Earth Surface Processes and Landforms, 41(3),

881 378-391. DOI: 10.1002/esp.3836

882 Mastronuzzi G, Sansò P. 2004. Large boulder accumulations by extreme waves

883 along the Adriatic coast of southern Apulia (Italy). Quaternary International, 120(1).

884 173-184.

885 Miller IM, Warrick JA. 2012. Measuring sediment transport and bed disturbance with

886 tracers on a mixed beach. Marine Geology 299: 1-7. DOI:

$887 \quad$ 10.1016/j.margeo.2012.01.002

888 Miller IM, Warrick JA, Morgan C. 2011. Observations of coarse sediment movements

889 on the mixed beach of the Elwha Delta, Washington. Marine Geology 282(3): 201-

890 14. DOI: 10.1016/j.margeo.2011.02.012

891 Moses CA. 2014. The rock coast of the British Isles: shore platforms. Geological

892 Society, London, Memoirs. 40(1): 39-56. DOI: 10.1144/M40.4

893 Mottershead D, Bray M, Soar P, Farres PJ. 2014. Extreme wave events in the

894 central Mediterranean: Geomorphic evidence of tsunami on the Maltese Islands.

895 Zeitschrift für Geomorphologie 58(3): 385-411. DOI: 10.1127/0372-8854/2014/0129 
896 Müller G, Wolters G, Cooker MJ. 2003. Characteristics of pressure pulses 897 propagating through water-filled cracks. Coastal Engineering. 1;49 (1-2): 83-98. DOI:

898 10.1016/S0378-3839(03)00048-6

899 Nandasena NA, Paris R, Tanaka N. 2011a. Numerical assessment of boulder 900 transport by the 2004 Indian ocean tsunami in Lhok Nga, West Banda Aceh

901 (Sumatra, Indonesia). Computers \& Geosciences 37(9): 1391-1399. DOI:

$902 \quad 10.1016 /$ j.cageo.2011.02.001

903 Nandasena NA, Paris R, Tanaka N. 2011b. Reassessment of hydrodynamic 904 equations: minimum flow velocity to initiate boulder transport by high energy events 905 (storms, tsunamis). Marine Geology 281(1): 70-84. DOI:

906 10.1016/j.margeo.2011.02.005

907 Nandasena NA, Tanaka N, Sasaki Y, Osada M. 2013. Boulder transport by the 2011 908 Great East Japan tsunami: Comprehensive field observations and whither model 909 predictions? Marine Geology 346: 292-309. DOI: 10.1016/j.margeo.2013.09.015

910 Nathan Bradley D, Tucker GE. 2012. Measuring gravel transport and dispersion in a 911 mountain river using passive radio tracers. Earth Surface Processes and Landforms 912 37(10): 1034-1045. DOI: 10.1002/esp.3223

913 Naylor LA, Stephenson WJ, Smith H, Way O, Mendelssohn J, Cowley A. 2016.

914 Geomorphological control on boulder transport and coastal erosion before, during 915 and after an extreme extra-tropical cyclone. Earth Surface Processes and Landforms 916 41(5): 685-700. DOI: 10.1002/esp.3900 
917 Naylor LA, Stephenson WJ, Trenhaile AS. 2010. Rock coast geomorphology: recent

918 advances and future research directions. Geomorphology 114(1):3-11. DOI:

919 10.1016/j.geomorph.2009.02.004

920 Nichols $\mathrm{MH}$. 2004. A radio frequency identification system for monitoring coarse

921 sediment particle displacement. Applied Engineering in Agriculture 20(6): 783-787.

922 DOI: 10.13031/2013.17727

923 Nordstrom KF, Jackson NL. 1993. Distribution of surface pebbles with changes in

924 wave energy on a sandy estuarine beach. Journal of Sedimentary Research 63(6):

$925 \quad 1152-1159$.

926 Noormets R, Crook KA and Felton EA. 2004. Sedimentology of rocky shorelines: 3.:

927 hydrodynamics of megaclast emplacement and transport on a shore platform, Oahu, 928 Hawaii. Sedimentary Geology, 172(1-2). 41-65.

929 Nott J. 2003a. Waves, coastal boulder deposits and the importance of the pre930 transport setting. Earth and Planetary Science Letters, 210(1-2). 269-276. DOI:

931 10.1016/S0012-821X(03)00104-3

932 Nott J. 2003b. Tsunami or storm waves?: Determining the origin of a spectacular

933 field of wave emplaced boulders using numerical storm surge and wave models and 934 hydrodynamic transport equations. Journal of Coastal Research: 348-356.

935 Ordnance Survey. 2017a. Accuracy [Online]. Available at:

936 https://www.ordnancesurvey.co.uk/business-and-government/help-and-

937 support/navigation-technology/os-net/accuracy.html [Accessed: 16 May 2017a]. 
938 Ordnance Survey. 2017b. OS-Net - Ordnance Survey [Online]. Available at:

939 https://www.ordnancesurvey.co.uk/gps/os-net-rinex-data/ [Accessed: 16 May 2017c].

940 Oregon RFID. 2017. HDX Long Range Readers [Online]. Available at:

941 https://www.oregonrfid.com/index.php?main_page=product_info\&cPath=1\&products

942 _id=6\&zenid=osn1jj|3mico7k8|9j0q5n3ho5 [Accessed: 12 September 2017].

943 Osborne PD. 2005. Transport of gravel and cobble on a mixed-sediment inner bank

944 shoreline of a large inlet, Grays Harbor, Washington. Marine Geology 224(1): 145-

945 56. DOI: $10.1016 /$ j.margeo.2005.08.004

946 Osborne PD, Macdonald N, Curtiss G. 2011. Measurements and Modeling of Gravel 947 Transport under Wind Waves, Vessel-Generated Waves, and Tidal Currents. Journal 948 of Coastal Research. Special Issue 59: 165-172. DOI: 10.2112/SI59-017.1

949 Paris R, Naylor LA, Stephenson WJ. 2011. Boulders as a signature of storms on 950 rock coasts. Marine Geology 283 (1-4): 1-11. DOI: 10.1016/j.margeo.2011.03.016

951 Pérez-Alberti A, Trenhaile AS. 2015a. An initial evaluation of drone-based monitoring 952 of boulder beaches in Galicia, north-western Spain. Earth Surface Processes and 953 Landforms 40(1): 105-111. DOI: 10.1002/esp.3654

954 Pérez-Alberti A, Trenhaile AS. 2015b. Clast mobility within boulder beaches over two 955 winters in Galicia, northwestern Spain. Geomorphology 248: 411-426. DOI:

$956 \quad$ 10.1016/j.geomorph.2015.08.001

957 Russell RC. 1960. The use of fluorescent tracers for the measurement of littoral drift. 958 Coastal Engineering Proceedings 1(7): 24. DOI: 10.9753/icce.v7.24 
959 Schaefer M, Woodyer T. 2015. Assessing absolute and relative accuracy of 960 recreation-grade and mobile phone GNSS devices: a method for informing device 961 choice. Area 47(2): 185-196. DOI: 10.1111/area.12172

962 Scheffers, A., Scheffers, S., Kelletat, D., \& Browne, T. (2009). Wave-emplaced 963 coarse debris and megaclasts in Ireland and Scotland: boulder transport in a high964 energy littoral environment. The Journal of Geology, 117(5), 553-573. DOI:

$965 \quad 10.1086 / 600865$

966 Sear DA, Lee MW, Oakley RJ, Carling PA, Collins MB. 2000. Coarse sediment 967 tracing technology in littoral and fluvial environments a review. Tracers in 968 Geomorphology, 21-55.

969 Shah-hosseini M, Morhange C, Beni AN, Marriner N, Lahijani H, Hamzeh M, 970 Sabatier F. 2011. Coastal boulders as evidence for high-energy waves on the Iranian 971 coast of Makran. Marine Geology 290(1): 17-28. DOI: 10.1016/j.margeo.2011.10.003

972 Sousa WP. 1979. Disturbance in marine intertidal boulder fields: the nonequilibrium 973 maintenance of species diversity. Ecology, 60(6), 1225-1239.

974 DOI:org/10.2307/1936969

975 Spiske M, Bahlburg H. 2011. A quasi-experimental setting of coarse clast transport 976 by the 2010 Chile tsunami (Bucalemu, Central Chile). Marine Geology, 289(1-4), 72977 85. DOI: 10.1016/j.margeo.2011.09.007

978 Steers JA, Smith DB. 1956. Detection of movement of pebbles on the sea floor by 979 radioactive methods. The Geographical Journal 122(3): 343-345. 
980 Stephenson WJ, Abazović A. 2016. Measuring Coastal Boulder Movement Under 981 Waves Using Tri-Axial Accelerometers. Journal of Coastal Research, 75(sp1), 607982 611. DOI: $10.2112 /$ SI75-122.1

983 Stephenson WJ, Kirk RM. 2000. Development of shore platforms on Kaikoura 984 Peninsula, South Island, New Zealand: Part one: the role of waves. Geomorphology 98532 (1-2): 21-41. DOI: 10.1016/S0169-555X(99)00061-6

986 Stephenson WJ, Naylor LA. 2011. Geological controls on boulder production in a 987 rock coast setting: insights from South Wales, UK. Marine Geology 283(1): 12-24. 988 DOI: 10.1016/j.margeo.2010.07.001

989 Sunamura, T. 1992. Geomorphology of rocky coasts (Vol. 3). John Wiley \& Son Ltd.

990 Switzer AD, Burston JM. 2010. Competing mechanisms for boulder deposition on the 991 southeast Australian coast. Geomorphology, 114(1-2), 42-54. DOI:

992 10.1016/j.geomorph.2009.02.009

993 Topcon. 2017. HiPer V - Topcon Positioning Systems, Inc. [Online]. Available at: 994 https://www.topconpositioning.com/gnss/integrated-gnss-receivers/hiper-v 995 [Accessed: 16 May 2017b].

996 Trenhaile A. 2002. Rock coasts, with particular emphasis on shore platforms. 997 Geomorphology, 48(1-3), 7-22. DOI: 10.1016/S0169-555X(02)00173-3

998 Trenhaile A. 2016. Rocky coasts - their role as depositional environments. Earth999 Science Reviews 159:1-13. DOI: 10.1016/j.earscirev.2016.05.001

1000 Van Sickle J. 2008. GPS for land surveyors. CRC Press. 
1001 Want R. 2006. An introduction to RFID technology. IEEE Pervasive Computing, 5(1), 1002 25-33. DOI: 10.1109/MPRV.2006.2

1003 Wright P, Cross JS, Webber NB. 1978. Aluminium pebbles: A new type of tracer for 1004 flint and chert pebble beaches. Marine Geology 27(1-2): 9-17. DOI: 10.1016/0025$10053227(78) 90069-5$

1006 Zingg T. 1935. Beitrag zur Schotteranalyse. Schweizerische Mineralogische und 1007 Petrographische Mitteilungen 15, 39-140. DOI: 10.3929/ethz-a-000103455

1008

1009

1010

1011

1012

1013

1014

1015 TABLES 
Table 1. Littoral tracer studies of coarse sediment reporting the selected

tracer technique, duration of study and rate of recovery.

\begin{tabular}{|c|c|c|c|c|c|}
\hline Authors \& date & Tracer method/technique & $\begin{array}{c}\text { Particle size (after Blair \& McPherson, } \\
\text { 1999) }\end{array}$ & $\begin{array}{l}\text { No. of deployed } \\
\text { tracers }\end{array}$ & Study duration & $\begin{array}{c}\text { Reported recovery } \\
\text { rate }\end{array}$ \\
\hline Kidson et al., 1958 & Radioactive & Size not specified - pebbles & 2000 & 6 weeks & $\sim 5 \%$ \\
\hline Jolliffe, 1964 & $\begin{array}{l}\text { Artificial (concrete) \& } \\
\text { painted }\end{array}$ & Coarse pebbles / fine cobbles & 2500 & 4.5 days & $58 \%$ \\
\hline $\begin{array}{l}\text { Nordstrom \& Jackson, } \\
1993\end{array}$ & Painted & Fine / coarse pebbles & $8.9 \mathrm{~kg}$ & 29 days & $6 \%(0.53 \mathrm{~kg})$ \\
\hline $\begin{array}{l}\text { Ciavola \& Castiglione, } \\
2009\end{array}$ & Painted & Cobbles $(>64 \mathrm{~mm})$ & $35.1 \mathrm{~kg}$ & 4 days & $30 \%(10.5 \mathrm{~kg})$ \\
\hline Naylor et al., 2016 & Painted and numbered & Coarse cobbles - fine / medium boulders & 48 & 4 days & $81 \%$ \\
\hline Wright et al, 1978 & Aluminium & Very coarse pebbles & 75 & 17 days & $61 \%$ \\
\hline Bray et al., 1996 & Aluminium \& Electronic & $34-65 \mathrm{~mm}$ : very coarse pebbles & $\begin{array}{l}246 \& 139 \\
\text { respectively }\end{array}$ & 6 weeks & $\begin{array}{l}47-96 \% \& 80-100 \% \\
\text { respectively }\end{array}$ \\
\hline Osborne, 2005 & Magnetic & $\begin{array}{l}\text { Intermediate axis between } 19-108 \mathrm{~mm} \text { : } \\
\text { coarse pebbles / fine cobbles }\end{array}$ & 90 & 2 months & $93 \%$ \\
\hline Allan et al., 2006 & RFID & Mode value $90.5 \mathrm{~mm}$ : fine cobbles & 400 & 17 months & $\begin{array}{l}90 \% \text { after } 8 \text { months } \\
18 \% \text { after } 17 \text { months }\end{array}$ \\
\hline Curtiss et al., 2009 & RFID & 23mm: coarse pebbles & 96 & 14 months & $\begin{array}{l}>80 \% \text { throughout } \\
\text { survey }\end{array}$ \\
\hline Dickson et al., 2011 & RFID & $\begin{array}{l}\text { Minimum long and short axes of } 60 \mathrm{~mm} \text { and } \\
\qquad 30 \mathrm{~mm} \text { respectively }\end{array}$ & 180 & 8 months & $0-30 \%$ \\
\hline Miller \& Warwick., 2012 & RFID & 64-128mm: fine cobbles & 54 & 24 hours & $93-100 \%$ \\
\hline Dolphin et al., 2016 & RFID & Size not specified: gravel & 940 & 3 years & $78 \%$ on completion \\
\hline Han et al., 2017 & RFID & $64 \mathrm{~mm}$ : very coarse pebbles / fine cobbles & 200 & 2 days & $33 \%$ \\
\hline
\end{tabular}


1016 Table 2. The effect of tag approach direction on detection range; all values

1017 expressed in metres.

\begin{tabular}{|c|c|c|c|c|c|c|c|c|c|}
\hline \multirow[b]{2}{*}{$\begin{array}{c}\text { Tag } \\
\text { approach }\end{array}$} & \multicolumn{5}{|c|}{ Mean detection range $(\mathrm{m})$} & \multirow[b]{2}{*}{ Mean } & \multirow[b]{2}{*}{$\begin{array}{l}\text { Min. } \\
\text { range }\end{array}$} & \multirow[b]{2}{*}{$\begin{array}{c}\text { Max. } \\
\text { range }\end{array}$} & \multirow[b]{2}{*}{$\begin{array}{c}\text { Std } \\
\text { deviation }\end{array}$} \\
\hline & Tag 1 & Tag 2 & Tag 3 & Tag 4 & Tag 5 & & & & \\
\hline North & 0.78 & 0.78 & 0.78 & 0.78 & 0.76 & 0.77 & 0.72 & 0.84 & 0.03 \\
\hline East & 0.42 & 0.44 & 0.43 & 0.43 & 0.42 & 0.43 & 0.36 & 0.5 & 0.03 \\
\hline South & 0.61 & 0.62 & 0.62 & 0.63 & 0.62 & 0.62 & 0.56 & 0.69 & 0.03 \\
\hline West & 0.35 & 0.34 & 0.35 & 0.34 & 0.34 & 0.34 & 0.29 & 0.41 & 0.03 \\
\hline
\end{tabular}

1018

1019 Table 3. Particle size and shape of indigenous and tagged boulders, mean boulder 1020 size classifications are based on the length of the intermediate axis.

\begin{tabular}{|c|c|c|c|}
\hline & & $\begin{array}{c}\text { Bembridge } \\
\text { Ledge }\end{array}$ & Black Rock \\
\hline \multirow{2}{*}{ Size } & Mean indigenous boulder size $(\mathrm{m})$ & 0.76 & 0.84 \\
\hline & Mean tagged boulder size $(\mathrm{m})$ & 0.78 & 0.82 \\
\hline \multirow{4}{*}{$\begin{array}{c}\text { Shape (Zingg, } \\
1935)\end{array}$} & Disc (\% indigenous / tagged) & $(65 / 66)$ & $(49 / 46)$ \\
\hline & Blade (\% indigenous / tagged) & $(32 / 30)$ & $(19 / 15)$ \\
\hline & Rod (\% indigenous / tagged) & $(1 / 2)$ & $(13 / 11)$ \\
\hline & Sphere (\% indigenous / tagged $)$ & $(2 / 2)$ & $(19 / 28)$ \\
\hline
\end{tabular}

1021

1022

1023

1024 
1025 Table 4. RFID tagged morphological boulder zones, pre-transport setting and

1026 description; Bembridge Ledge (BL) and Black Rock (BR).

\begin{tabular}{|c|c|c|c|c|}
\hline $\begin{array}{c}\text { Morphological boulder } \\
\text { zones }\end{array}$ & $\begin{array}{l}\text { Pre-transport } \\
\text { setting }\end{array}$ & Description & $\begin{array}{l}\text { Number } \\
\text { (BL / BR) }\end{array}$ & Figure \\
\hline $\begin{array}{l}\text { Located on the seaward side } \\
\text { of the shore platform. }\end{array}$ & $\begin{array}{l}\text { Platform edge } \\
\text { (detached) }\end{array}$ & $\begin{array}{l}\text { Boulders located at the edge of the shore platform } \\
\text { which are fully detached and awaiting transport. The } \\
\text { tagged clasts located here are impeded in their } \\
\text { transport potential by the raised shore platform edge. }\end{array}$ & $13 / 3$ & $4(1)$ \\
\hline $\begin{array}{l}\text { Located at the shore platform } \\
\text { edge. }\end{array}$ & $\begin{array}{l}\text { Platform edge } \\
\text { (joint bound) }\end{array}$ & $\begin{array}{l}\text { Described by Nott (2003a) as joint bound blocks. The } \\
\text { geologically discontinuous lithology at Bembridge } \\
\text { creates angular blocks at the platform edge. These } \\
\text { blocks may, or may not, be fully detached from the } \\
\text { platform edge being constrained on one or more sides } \\
\text { by the surrounding strata. }\end{array}$ & $4 / 2$ & $\begin{array}{l}6 \& 9 \\
\text { (inset) }\end{array}$ \\
\hline $\begin{array}{l}\text { Located on the shore platform } \\
\text { (limited transport potential } \\
\text { owing to local topography } \\
\text { and/or morphology). }\end{array}$ & $\begin{array}{l}\text { Platform top } \\
\text { (constrained) }\end{array}$ & $\begin{array}{l}\text { Boulders deposited on the platform, the transport of } \\
\text { which is considered to be restricted by local } \\
\text { topography and/or morphological features, i.e., } \\
\text { positioned in a depression or imbricate against a rock } \\
\text { feature (scarp) or other boulder/s (Trenhaile 2016). }\end{array}$ & $18 / 25$ & $11 a$ \\
\hline $\begin{array}{l}\text { Located on the shore platform } \\
\text { (greater transport potential } \\
\text { owing to local topography } \\
\text { and/or morphology). }\end{array}$ & $\begin{array}{c}\text { Platform top } \\
\text { (unconstrained) }\end{array}$ & $\begin{array}{l}\text { Boulders deposited on the platform, further transport is } \\
\text { unhindered by local topography and/or morphological } \\
\text { features (Trenhaile 2016). }\end{array}$ & $15 / 24$ & 7 \\
\hline
\end{tabular}

1027

1028

1029

1030

1031

1032 
2 Table 5. Details the suggested boulder characteristics that should be recorded at the time of tag insertion.

\begin{tabular}{|c|c|c|c|c|}
\hline Item & $\begin{array}{c}\text { Noted } \\
\text { characteristics }\end{array}$ & Description & Use & Figure \\
\hline 1 & $\begin{array}{l}\text { Boulder axial } \\
\text { dimensions }\end{array}$ & $\begin{array}{l}\text { The long }(L) \text {, intermediate }(I) \text { and short }(S) \text { axis } \\
\text { dimensions are measured. }\end{array}$ & $\begin{array}{l}\text { To establish boulder shape and } \\
\text { approximate mass. }\end{array}$ & 6 \\
\hline 2 & Rock type & $\begin{array}{l}\text { Noted to determine rock density by conducting } \\
\text { laboratory testing on rock samples using the } \\
\text { displacement method. }\end{array}$ & $\begin{array}{l}\text { Values used to calculate boulder } \\
\text { mass. }\end{array}$ & N/A \\
\hline 3 & $\begin{array}{l}\text { Long }(\mathrm{L}) \text { axis } \\
\text { orientation }\end{array}$ & $\begin{array}{l}\text { Recording the boulder orientation offers insight } \\
\text { to the transport direction as mobilised boulders } \\
\text { often have the } L \text {-axis aligned perpendicular or } \\
\text { parallel to the direction of travel (Nott, 2003b). }\end{array}$ & $\begin{array}{l}\text { Subsequent measurement of the } L- \\
\text { axis orientation during relocation } \\
\text { surveys can help establish where } \\
\text { small rotational movements } \\
\text { (entrainment) may have occurred } \\
\text { between surveys. }\end{array}$ & N/A \\
\hline 4 & $\begin{array}{l}\text { Distinguishing } \\
\text { features }\end{array}$ & $\begin{array}{l}\text { Distinctive boulder shape, impact scars, } \\
\text { abrasion markings or biological indicators such } \\
\text { as algal growth, evidence of boring and/or the } \\
\text { presence of organisms (e.g. limpets, barnacles). }\end{array}$ & $\begin{array}{l}\text { This may suggest the direction or } \\
\text { mode of transport and provide } \\
\text { insight to the pre-transport setting } \\
\text { and direction and/or mode of } \\
\text { transport. }\end{array}$ & $7 \& 9$ \\
\hline 5 & Morphological context & $\begin{array}{l}\text { Is the boulder topographically constrained in its } \\
\text { ability to be transported, e.g. buried, imbricate } \\
\text { against other clasts, located within a depression } \\
\text { or against a raised scarp? Accumulated } \\
\text { sediment may result in boulder burial during } \\
\text { subsequent surveys restricting mobility. }\end{array}$ & $\begin{array}{l}\text { Provides detail on the morphological } \\
\text { setting which is known to influence } \\
\text { boulder mobility (Naylor et al., 2016). }\end{array}$ & $\begin{array}{c}8,9 \& \\
11 a\end{array}$ \\
\hline 6 & Boulder photograph & $\begin{array}{l}\text { Individual boulder images capture a broader } \\
\text { visual account of the boulder setting. }\end{array}$ & $\begin{array}{l}\text { Used to compile a boulder } \\
\text { identification inventory for each } \\
\text { survey. This proved useful for tag } \\
\text { relocation and comparative } \\
\text { purposes throughout the study. }\end{array}$ & $\begin{array}{c}1,6,7 \\
8,9 \& \\
11\end{array}$ \\
\hline 7 & $\begin{array}{l}\text { Record the boulder } \\
\text { location using the TIP }\end{array}$ & $\begin{array}{l}\text { The DGNSS rover pole is placed next to the TIP } \\
\text { and the coordinate recorded (Figure 7). The last } \\
\text { 4-digits of the unique tag ID code are entered to } \\
\text { the DGNSS interface for processing following } \\
\text { survey completion. }\end{array}$ & $\begin{array}{l}\text { Provides a spatial and temporal } \\
\text { account of the boulder location. }\end{array}$ & $7 \& 8$ \\
\hline 8 & $\begin{array}{l}\text { Noting the position of } \\
\text { the orientation hole }\end{array}$ & $\begin{array}{l}\text { Noting the location of the orientation hole relative } \\
\text { to the TIP (above the TIP at time of tag } \\
\text { deployment). This is of relevance when } \\
\text { conducting relocation surveys. }\end{array}$ & $\begin{array}{l}\text { Identifies incidents of boulder } \\
\text { overturning during transport if } \\
\text { orientated differently to previous } \\
\text { survey. }\end{array}$ & 7 \\
\hline
\end{tabular}


1037 Table 6. Summary of boulder transport data from Bembridge Ledge and Black Rock 1038 from July 2015 to May 2017. 
2 BEMBRIDGE LEDGE

3 (50 RFID tagged boulders)

\section{Survey Period}

From

To

25th July '15 3rd Feb '16

3rd Feb'16 17th Feb '16

10 17th Feb'16 1st Apr'16

11 1st Apr'16 23rd Sept'16

12 23rd Sept'16 25th Nov'16

13 25th Nov'16 8th Feb '17

8th Feb'17 5th May '17

15 TOTAL

TOTA

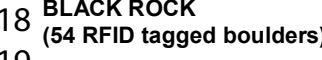

22nd Feb '17

TOTAL

24th May '17

TOTALS

$\begin{array}{cccc}\begin{array}{c}\text { Boulders } \\ \text { transported } \\ \text { (\% of total) }\end{array} & \begin{array}{c}\text { CTD }(\mathbf{m}): \\ \text { (Max IBTD })\end{array} & \begin{array}{c}\text { CTD } \\ \text { (\% of } \\ \text { total) }\end{array} & \begin{array}{c}\text { Mean transport } \\ \text { dist. (m) }\end{array} \\ 21(42) & 49.2(16.1) & 42 & 2.3 \\ 12(24) & 12.1(7.5) & 10 & 1.0 \\ 13(26) & 6.3(1.2) & 5 & 0.5 \\ 11(22) & 5.5(1.6) & 5 & 0.5 \\ 13(26) & 12.7(4.6) & 11 & 1.0 \\ 15(30) & 27.2(8.9) & 23 & 1.8 \\ 9(18) & 4.0(2.3) & 4 & 0.5\end{array}$

94

117.0

1.1 (st. dev 0.7)

Mean transport
dist. between
surveys (m/day)

\section{Mean mass of} transported
boulders $(t)$ :

(Max. mass)

\subsection{5}

\subsection{6}$$
0.14
$$

0.03

0.20

0.36

0.05

$$
\begin{aligned}
& 0.5(1.1) \\
& 0.6(1.2) \\
& 0.6(1.2) \\
& 0.5(1.3) \\
& 0.5(1.2) \\
& 0.5(1.2) \\
& 0.5(1.3)
\end{aligned}
$$

Mean
direction of
transport $\left({ }^{\circ}\right)$

\section{9}

226

177

192

233

246

260
Boulders (\% of total)

$15(28)$
$12(22)$
$12(22)$
$12(22)$
$4(7)$
$6(11)$
$7(13)$
$2(4)$
70

\section{CTD (m):} (Max IBTD*)

$\begin{array}{lcc}\text { CTD } \\ \text { (\% of } & \text { Mean transport } & \text { Mean transport } \\ \text { total) } & \text { dist. }(m) & \begin{array}{c}\text { dist. between } \\ \text { surveys (m/day) }\end{array}\end{array}$

Mean mass of transported boulders (t):

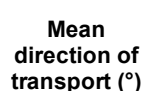

$\begin{array}{ccc}9.3(2.9) & 14 & 0.3 \\ 6.9(2.8) & 10 & 0.6 \\ 10.5(4.0) & 15 & 0.9 \\ 27.7(7.8) & 41 & 2.3 \\ 1.3(0.8) & 2 & 0.3 \\ 9.6(3.1) & 14 & 1.6 \\ 1.2(0.4) & 2 & 0.2 \\ 1.1(0.8) & 2 & 0.6\end{array}$

0.06
0.20
0.24
0.27
0.01
0.10
0.02
0.01

67.6

0.9 (st. dev 0.7)

184.6

$$
\begin{gathered}
0.4(1.8) \\
0.6(1.8) \\
1.0(5.0) \\
2.0(11.9) \\
0.4(0.7) \\
3.4(11.9) \\
0.7(1.5) \\
0.3(0.4)
\end{gathered}
$$

164

Overturning
events

Max. Hs
between
survey
period $(\mathrm{m})$

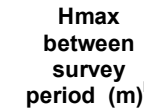

\section{3}

2.5

4.2

1.8

4.0

2.4

2.5

5.4
4.0
6.6
3.0
6.8
4.0
4.3

\section{Overturning
events} $\begin{array}{cc}\begin{array}{c}\text { Max. Hs } \\ \text { between }\end{array} & \begin{array}{c}\text { Hmax } \\ \text { between }\end{array} \\ \text { survey } & \text { survey } \\ \text { period }(m)^{\mathrm{a}} & \text { period }(m)^{b}\end{array}$

Date of storm activity (named where applicable).

Mean tag recovery
rate

$\begin{array}{ll}2.2 & 3.9 \\ 3.3 & 5.4 \\ 2.6 & 4.8 \\ 4.2 & 6.6 \\ 1.5 & 2.4 \\ 4.0 & 6.8 \\ 2.4 & 4.0 \\ 2.5 & 4.3\end{array}$

26th Jul '15

3rd Jan ' 16

7th Jan '16

28th Mar '16 (Katie)

20th Aug '16

20th Nov '16 (Angus)

3rd Feb ' 17

22nd Mar '17

$81 \%$

$93 \%$

$100 \%$

$100 \%$

$100 \%$

$98 \%$

$91 \%$

$100 \%$

95\%

\section{$1039{ }^{a}$ - Maximum significant wave height $(\mathrm{m})$ - as recorded by the Channel Coast Observatory wave buoy.}

$1040{ }^{b}$ - Maximum wave height $(m)$ - as recorded by the Channel Coast Observatory wave buoy. 
$1041 *$ - NOTE: Additional detail on IBTD values is provided in the supplementary material. 


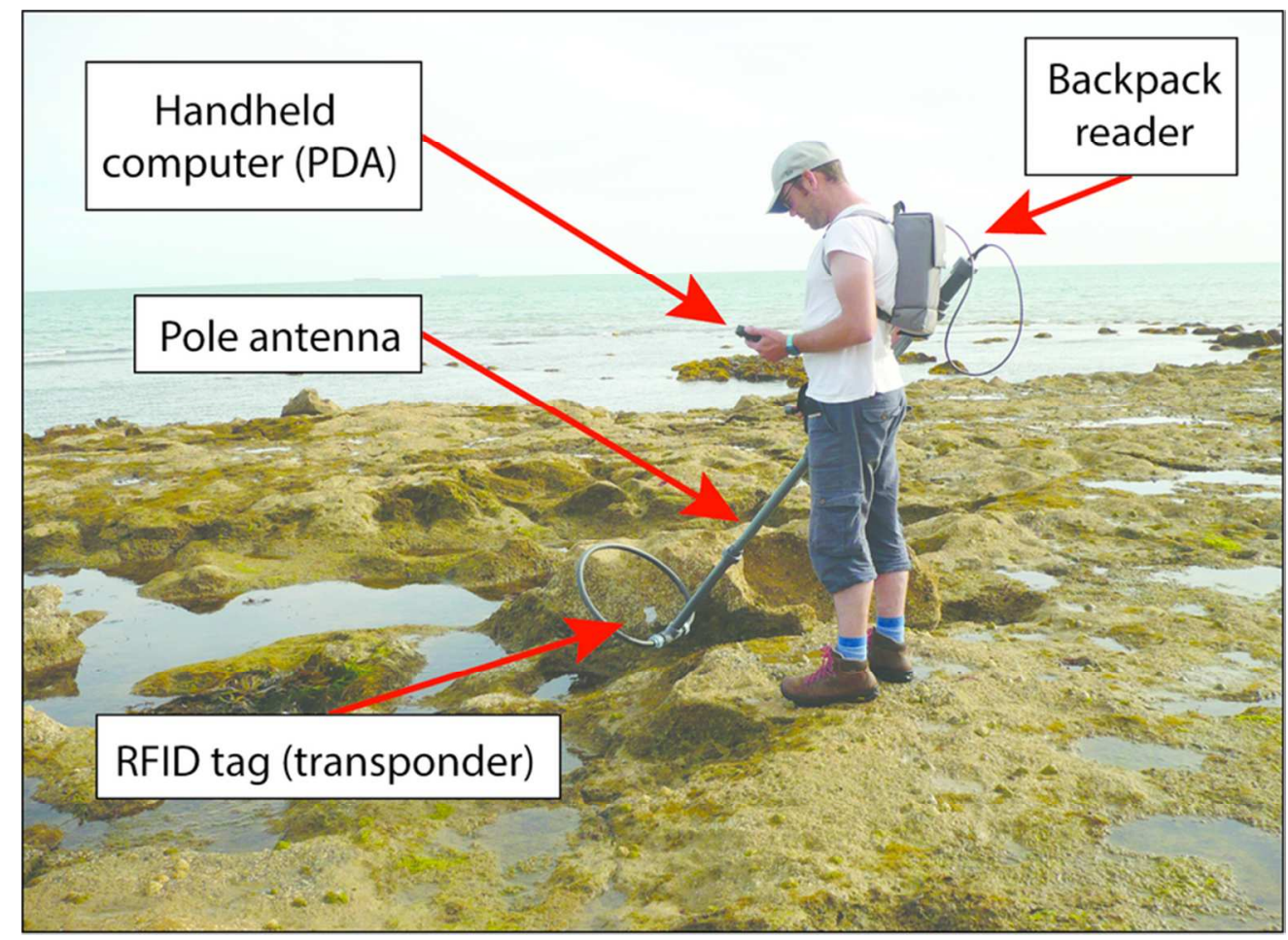

Figure 1. RFID detection equipment. (Photo, M. Schaefer).

$73 \times 54 \mathrm{~mm}(300 \times 300 \mathrm{DPI})$ 


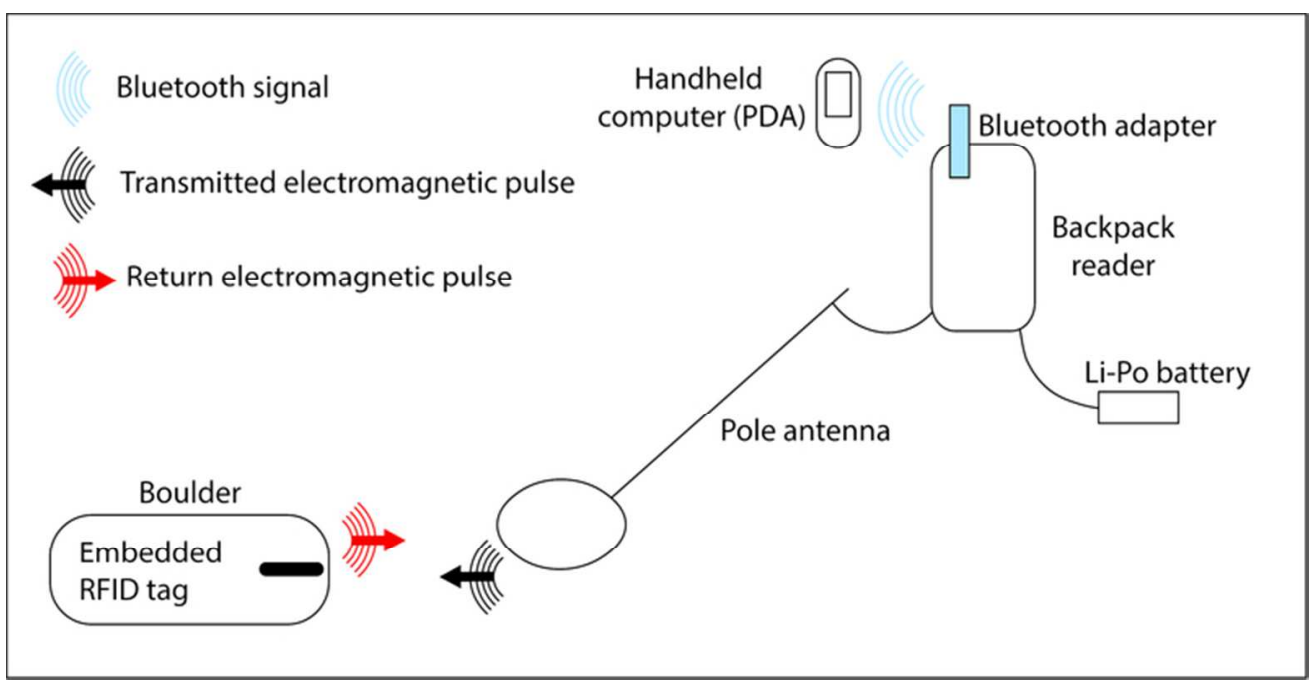

Figure 2. Schematic diagram of RFID operation illustrating signal transmittance to/from a boulder embedded RFID tag.

$67 \times 34 \mathrm{~mm}(300 \times 300$ DPI $)$ 


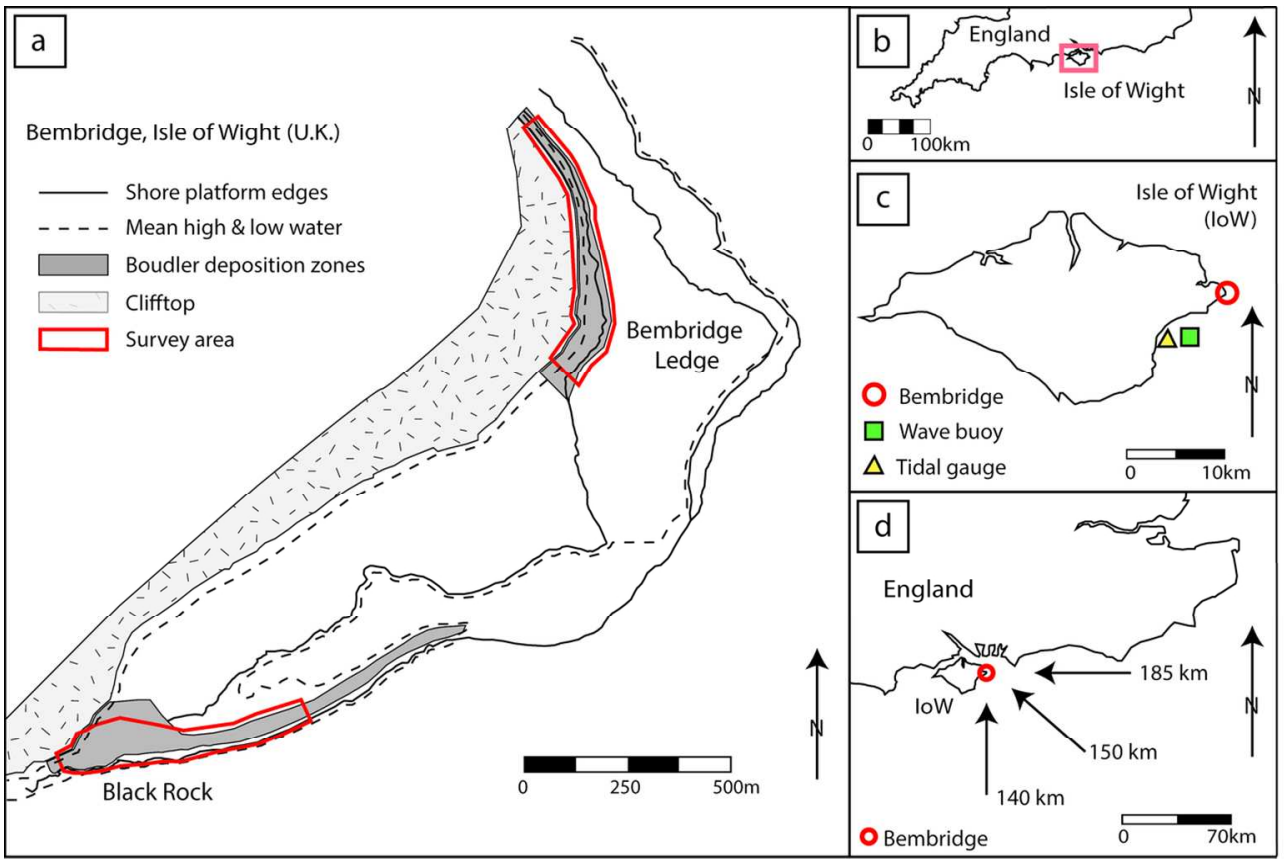

Figure 3. Bembridge study sites. (a) Black Rock and Bembridge Ledge - tagged boulders are located within the survey areas; (b) Isle of Wight's geographic location within the U.K.; (c) proximity of wave and tidal recording locations relative to the study site; (d) fetch distances to the study site.

$120 \times 79 \mathrm{~mm}(300 \times 300$ DPI $)$ 
Figure 4. Boulder detachment, transport and deposition at Bembridge Ledge. The clearly defined bedding and jointing at the platform terminus facilitates the production of boulders via quarrying and undermining. (1) detached boulders deposited seaward of the platform edge awaiting transport; (2) transported boulders deposited upon the gravel beach. Boulder transport pathways are highlighted. 


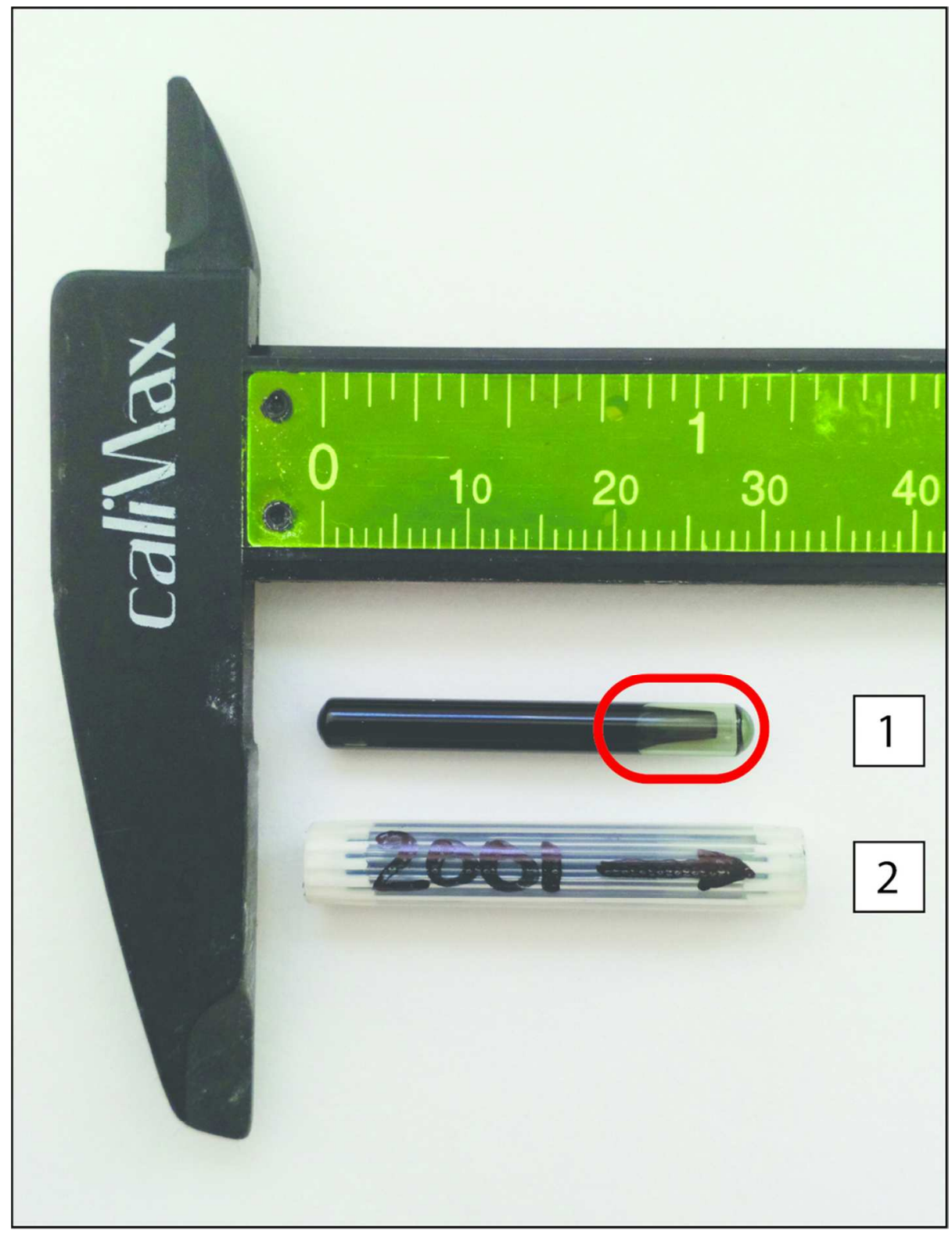

Figure 5. RFID tag; (1) 32mm RFID tag, the copper coils are located in the transparent end of the tag, circled; (2) RFID tag within a numbered protective silicone sleeve.

$89 \times 117 \mathrm{~mm}(300 \times 300 \mathrm{DPI})$ 


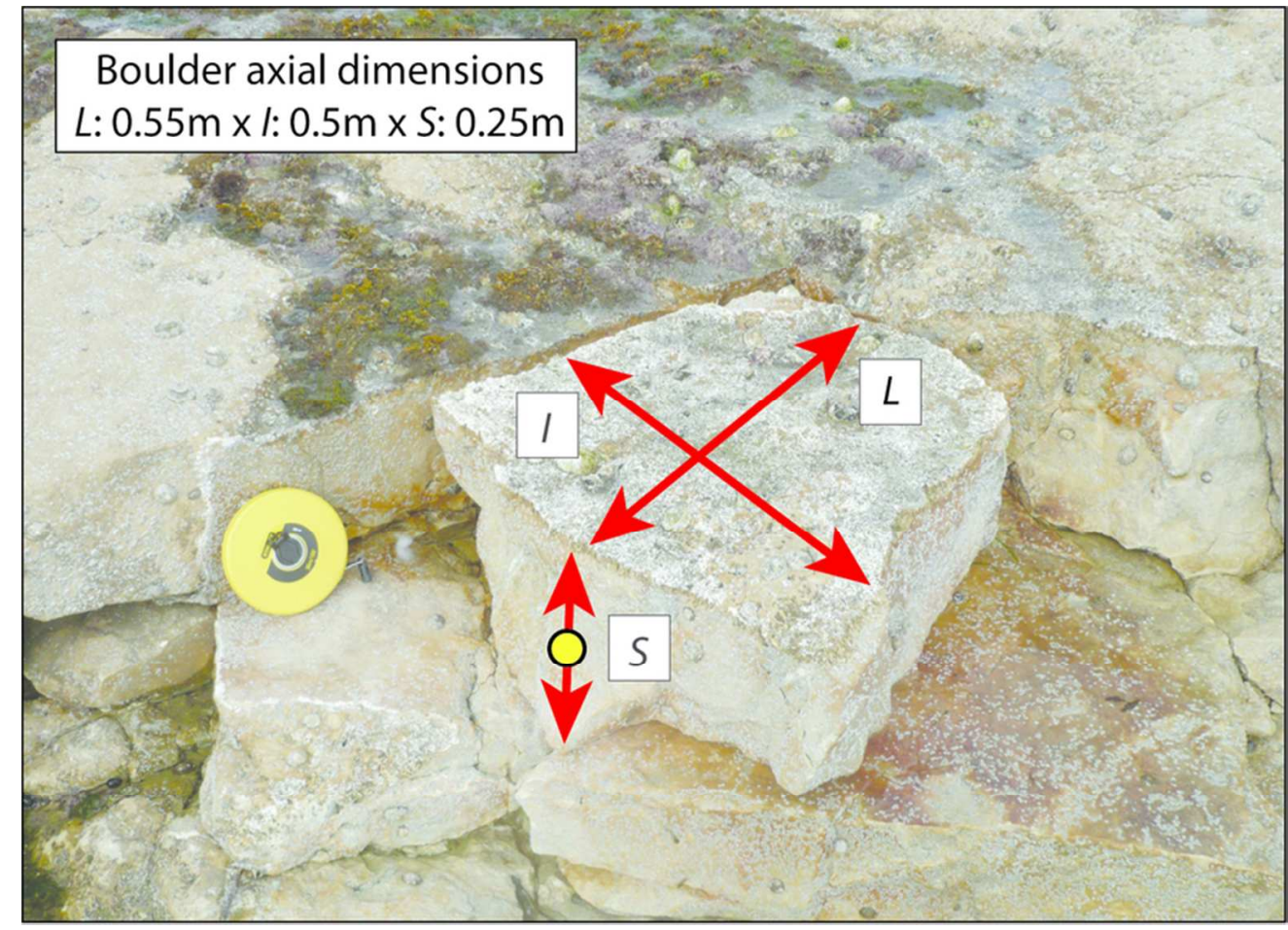

Figure 6. Recommended tag insertion point (TIP) within the S-axis indicated by the circle with the recorded boulder axial dimensions.

$75 \times 54 \mathrm{~mm}(300 \times 300$ DPI $)$ 


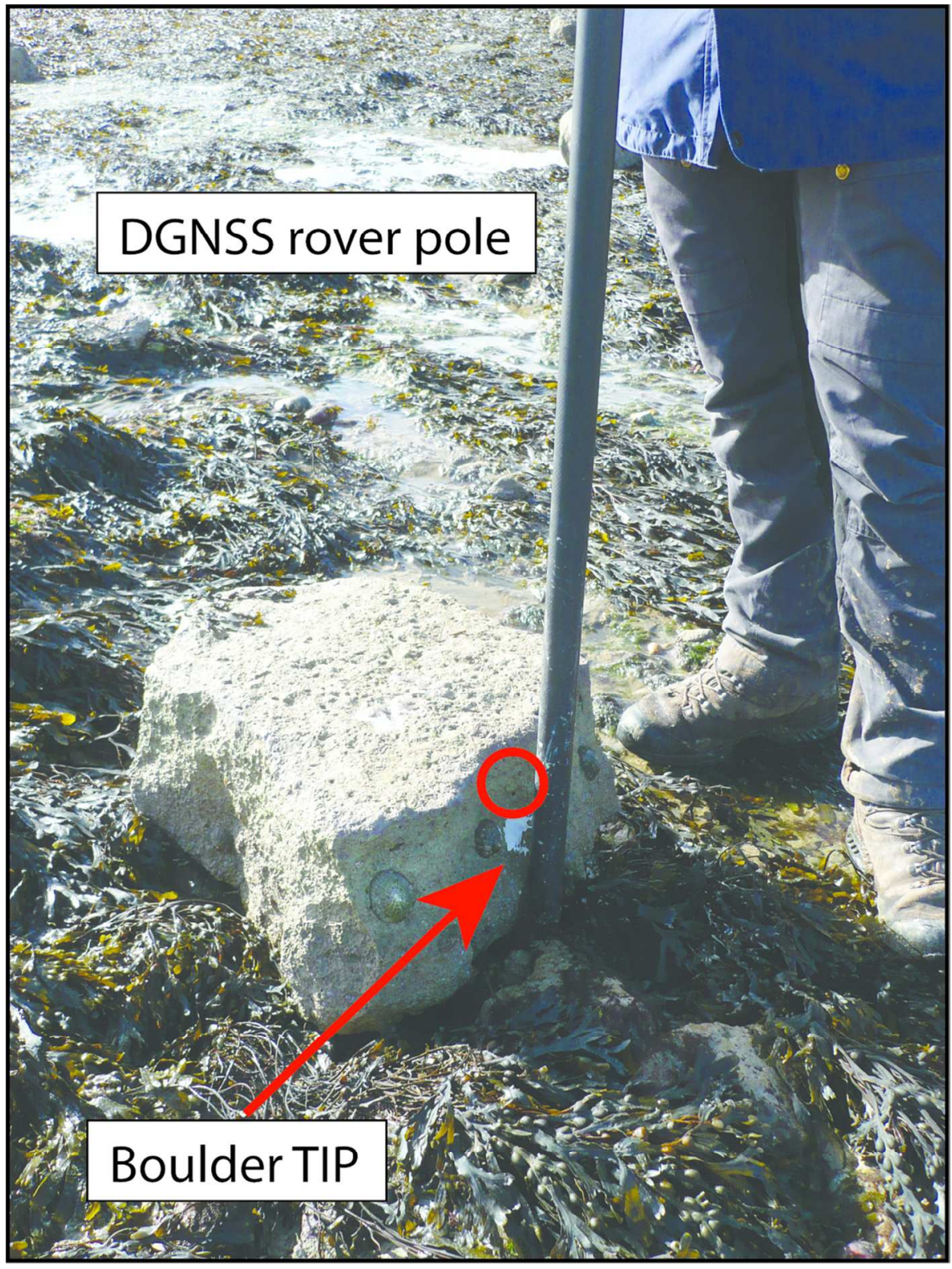

Figure 7. Recording the boulder location, the DGNSS pole is positioned against the TIP. The orientation hole is located above the TIP, (circled), indicating the boulders upward orientation at the time of relocation.

$100 \times 133 \mathrm{~mm}(300 \times 300 \mathrm{DPI})$ 


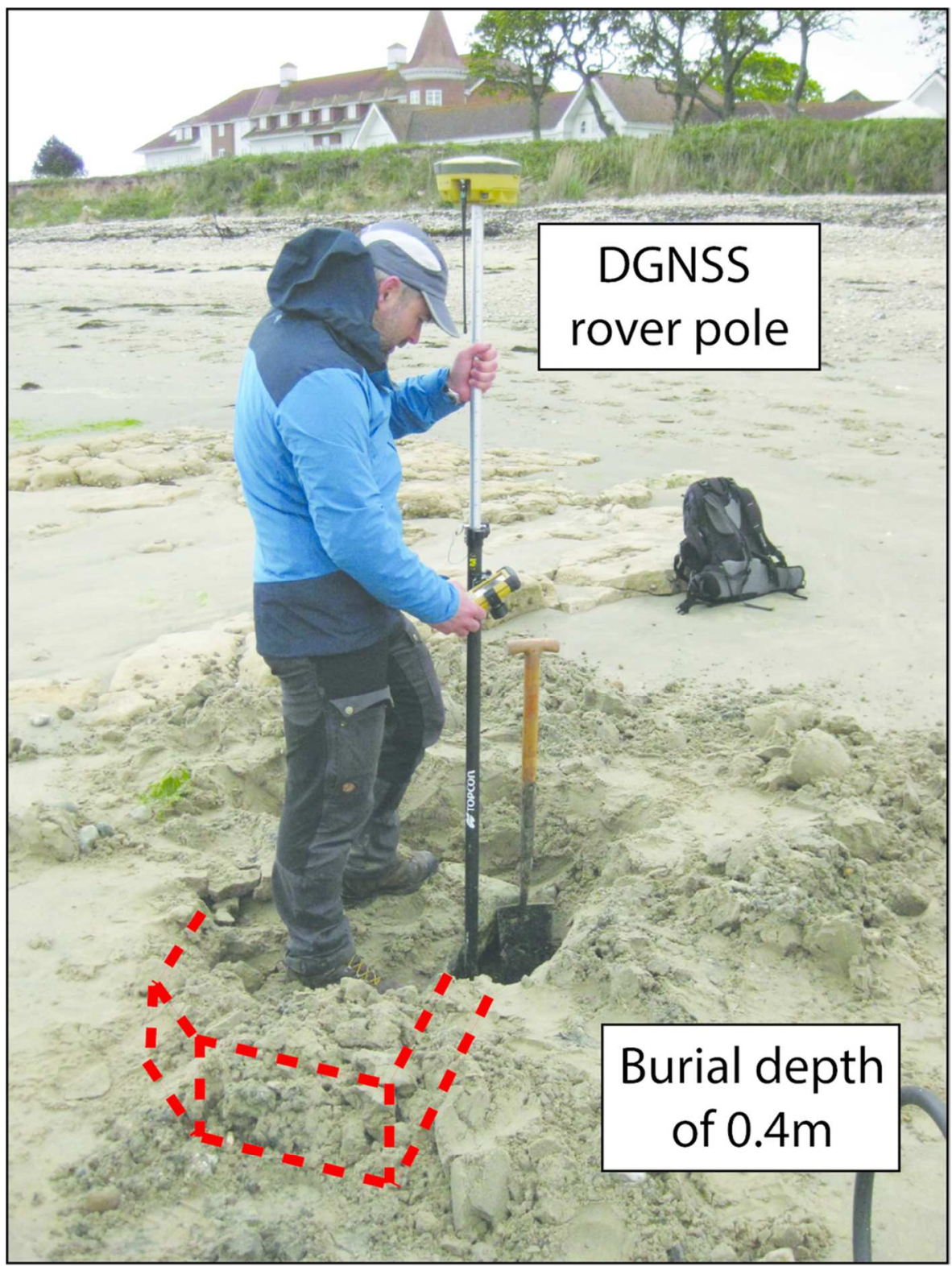

Figure 8. RFID tagged boulder relocated and excavated following the seasonal accretion of sand during the summer months. The TIP is being recorded with the DGNSS rover, the dashed line represents the remaining buried boulder.

$84 \times 113 \mathrm{~mm}(300 \times 300$ DPI $)$ 
Figure 9. Evidence of transport at Bembridge Ledge (RFID tag ID: 1127). Boulder location recorded on 3rd February 2016, (circle), relocated $7.2 \mathrm{~m}$ from its previously recorded position on 17 th February 2016 . The arrow indicates the direction of transport. Algal growth present on the underside of the boulder indicates overturning during transport. Inset: pre-transport setting, in-situ boulder prior to displacement. Note the extensive algal growth on the exposed upper plane (pad for scale: $0.25 \times 0.3 \mathrm{~m}$ ). 


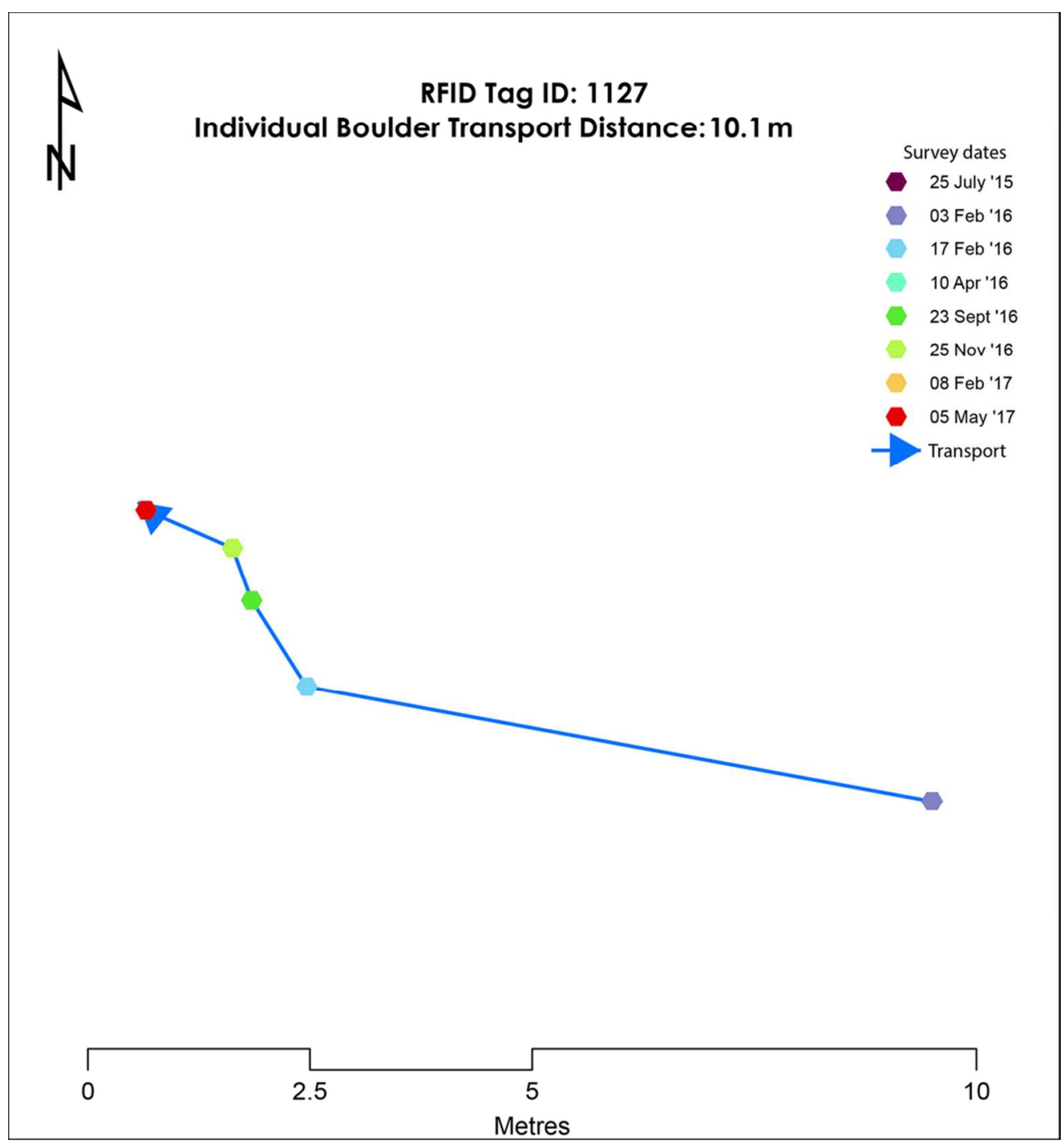

Caption : Figure 10. ArcGIS visual output documenting the direction of incremental step lengths and the Individual Boulder Transport Distance (IBTD) for the boulder pictured in figure 9 (RFID tag ID: 1127). The absence of colour markers associated with specific survey dates indicates that no transport was recorded on that date.

$90 \times 96 \mathrm{~mm}(300 \times 300 \mathrm{DPI})$ 
Figure 11. Evidence of transport at Black Rock (RFID tag ID: 1187). (a) boulder location recorded on 19th February 2016, (circle), relocated $6.4 \mathrm{~m}$ from its previously recorded position on 31st May 2016. Further landward progression was hindered following deposition against a boulder ridge; (b) the same boulder recorded on 1st September 2016, (circle), relocated $2.5 \mathrm{~m}$ seaward from its previously recorded position on 9th December 2016. The arrows indicate the direction of transport.

$113 \times 173 \mathrm{~mm}(300 \times 300 \mathrm{DPI})$ 
Figure 1. RFID detection equipment. (Photo, M. Schaefer).

Figure 2. Schematic diagram of RFID operation illustrating signal transmittance to/from a boulder embedded RFID tag.

Figure 3. Bembridge study sites. (a) Black Rock and Bembridge Ledge - tagged boulders are located within the survey areas; (b) Isle of Wight's geographic location within the U.K.; (c) proximity of wave and tidal recording locations relative to the study site; (d) fetch distances to the study site.

Figure 4. Boulder detachment, transport and deposition at Bembridge Ledge. The clearly defined bedding and jointing at the platform terminus facilitates the production of boulders via quarrying and undermining. (1) detached boulders deposited seaward of the platform edge awaiting transport; (2) transported boulders deposited upon the gravel beach. Boulder transport pathways are highlighted.

Figure 5. RFID tag; (1) $32 \mathrm{~mm}$ RFID tag, the copper coils are located in the transparent end of the tag, circled; (2) RFID tag within a numbered protective silicone sleeve.

Figure 6. Recommended tag insertion point (TIP) within the S-axis indicated by the circle with the recorded boulder axial dimensions.

Figure 7. Recording the boulder location, the DGNSS pole is positioned against the TIP. The orientation hole is located above the TIP, (circled), indicating the boulders upward orientation at the time of relocation.

Figure 8. RFID tagged boulder relocated and excavated following the seasonal accretion of sand during the summer months. The TIP is being recorded with the DGNSS rover, the dashed line represents the remaining buried boulder.

Figure 9. Evidence of transport at Bembridge Ledge (RFID tag ID: 1127). Boulder location recorded on 3rd February 2016, (circle), relocated $7.2 \mathrm{~m}$ from its previously recorded position on 17th February 2016. The arrow indicates the direction of transport. Algal growth present on the underside of the boulder indicates overturning during transport. Inset: pre-transport setting, in-situ boulder prior to displacement. Note the extensive algal growth on the exposed upper plane (pad for scale: $0.25 \mathrm{x}$ $0.3 \mathrm{~m})$.

Figure 10. ArcGIS visual output documenting the direction of incremental step lengths and the Individual Boulder Transport Distance (IBTD) for the boulder pictured in figure 9 (RFID tag ID: 1127). The absence of colour markers associated with specific survey dates indicates that no transport was recorded on that date.

Figure 11. Evidence of transport at Black Rock (RFID tag ID: 1187). (a) boulder location recorded on 19th February 2016, (circle), relocated 6.4m from its previously recorded position on 31st May 2016. Further landward progression was hindered following deposition against a boulder ridge; (b) the same boulder recorded on 1st September 2016, (circle), relocated $2.5 \mathrm{~m}$ seaward from its previously recorded position on 9th December 2016. The arrows indicate the direction of transport. 